Ana Dili Eğitimi Dergisi
Journal of Mother Tongue Education
ADED - JOMTE
www.anadiliegitimi.com

\title{
Cumhuriyet Dönemi Türkçe Eğitimi ve Öğretimi Programlarında Yazma Becerisi
}

\author{
Mehmet Temizkan ${ }^{1}$ \\ Arzu Atasoy ${ }^{2}$
}

\begin{abstract}
Özet
Bu araştırmanın amacı, Cumhuriyet döneminde uygulanan Türkçe eğitimi ve öğretimi programlarında yazma becerisinin nasıl ele alındığını tespit etmektir. Bu amaçla 1924 Lise Birinci Devre Müfredat Programı, 1929 Ortamektep Türkçe Programı, 1949 Ortaokul Türkçe Programı, 1981 İlköğretim Okulları Türkçe Eğitim Programı ve 2005 Türkçe Dersi $(6,7$, 8. Sınıflar) Öğretim Programı yazma becerisi açısından değerlendirilmiştir. Araştırmaya konu olan programların değerlendirilmesinde "amaçlar, açıklamalar, yöntem, davranış-kazanım ve düzeltmedeğerlendirme" olmak üzere toplam beş başlık belirlenmiştir. Araştırma nitel veri analizi tekniklerinden yararlanılarak gerçekleştirilen tarama modelinde betimsel bir çalışmadır. Araştırmada veri toplamak amacıyla doküman incelemesine başvurulmuştur. Sonuç olarak, Cumhuriyet döneminde uygulanan Türkçe eğitimi ve öğretimi programlarında yazma becerisine geniş bir yer ayrıldığı; araştırmada belirlenen başlıklar doğrultusunda yazma becerisiyle ilgili olarak oldukça önemli bilgiler verildiği tespit edilmiştir.
\end{abstract}

Anahtar Kelimeler: Yazma becerisi, Program, Türkçe öğretim programları.

\section{Writing Skill of Turkish Education Programs in Republic Period}

\begin{abstract}
The purpose of this study is to examine the writing skill in Turkish language education programs that are practiced during the Turkish Republic period. For this purpose, 1924 High School First Degree Curriculum, 1929 Secondary Turkish Program, 1949 Secondary Turkish Program, 1981 Primary Schools Turkish Education Program and the 2005 Turkish Courses $(6,7,8$ grades) Curriculum were evaluated in terms of writing skill. In the evaluation of programs that are the subject of the study, "functions, instructions, teaching techniques and approaches, language tasks and study skills, evaluation" are analyzed. This is a descriptive study that is carried out by making use of qualitative data analysis techniques in the survey model. In the study, to collect data the document reviews were referred to and inspected. As a result, it was determined that writing skill was discussed in detail in Turkish language course curriculum which was practised in Republic Period and given really important information was given about writing skill in accordance with the titles determined in the study.
\end{abstract}

Key Words: Writing skill, Curriculum, Turkish language programs.

\footnotetext{
${ }^{1}$ Doç. Dr. Mustafa Kemal Üniversitesi Eğitim Fakültesi Türkçe Eğitimi Bölümü. Hatay. E-posta: temizkan.mehmet@hotmail.com

${ }^{2}$ Arş. Gör. Mustafa Kemal Üniversitesi Eğitim Fakültesi Türkçe Eğitimi Bölümü. Hatay. E-posta: arzuatasoy2014@outlook.com
} 


\section{Giriş}

Günümüz dünyasında hemen bütün disiplinlerde yaşanan baş döndürücü gelişme ve değişmeler coğrafi sınırları âdeta ortadan kaldırmakta ve toplumları da bu değiş̧imin arkasından sürüklemektedir. Bu değişim ve dönüşümle birlikte geleceğin toplumlarını oluşturacak ve onları yönetecek nitelikli insan gücüne ihtiyaç duyulmaktadır. Gelişen toplumlarda ihtiyaç duyulan insan; yaratıcı ve hızlı düşünme, yeniliklere açık olma, çevresini tanıma ve gereksinimlerine göre onu en iyi şekilde değiştirebilme, yeni ürünler yaratabilme, kendisini doğru, açık ve anlaşılır bir şekilde ifade etme, girişken olma, eleştirel düşünme, problem çözebilme gibi niteliklere sahip olmalıdır. Bu durum, intiyaç duyulan insan tipinin yetiştirilmesinde birçok alanda olduğu gibi eğitim sistemlerinde de sürekli bir gelişme sağlanması gerekliliğini ortaya koymaktadır. Çünkü bir toplumun eğitim sistemi, mensubu olduğu bireylerin kendilerini geliştirmelerinde etkili olduğu gibi aynı zamanda toplumun sosyal, kültürel ve ekonomik anlamda ilerlemesinde de önemli bir role sahiptir.

Toplumların ihtiyaç duydukları insan modelinin yetiştirilmesinde en önemli rolü üstlenen eğitim faaliyetlerinin mutlaka sistemli yani programlı bir şekilde yürütülmesi gerekir. Bu gerçekten hareketle her ülke, kendi millî amaçlarını da göz önünde tutarak eğitim ve öğretim programlarını hazırlamaktadır. Türkçe Sözlük'te (2005) program, belirli şartlara ve düzene göre yapılması öngörülen işlemler bütünü, izlence; yapılacak bir işin bölümlerini, bölümlerin sırasını ve zamanını gösteren tasarı olarak tanımlanmaktadır. Herhangi bir dersin programında konu listesi, ders içeriği, çalışma programı, öğretim materyalleri, hedef davranışlar, okul içinde ve dışında planlanan unsurlar bulunmaktadır.

Nitelikli insan gücü yetiştirme çabaları bizi, içerikleri üzerinde düşünülmesi gereken "eğitim ve öğretim" şeklinde iki kavramla karşı karşıya getirmektedir. Bu iki kavram, anlamları açısından her ne kadar birbirine yakın görünse de aralarında bazı farklar vardır. Eğitim kavramı daha çok bireyleri hayata hazırlamakla yakından ilgilidir. Buna göre eğitim gören bireylerin toplum hayatındaki yerlerini alabilmek amacıyla gerekli beceri ve yaklaşımları kazanmaları, çeşitli etkinlikler yoluyla kişiliklerini geliştirmeleri gerekmektedir. O halde eğitim kavramı daha çok kişilik gelişimi ve günlük hayatta kullanılması gereken bazı becerileri kazanmakla ilgilidir. Buna karşın öğretim belirli amaçlara ulaşmak için gereken bilgileri verme işi, öğrenmeyi kolaylaştıracak etkinlikleri düzenleme, araç ve gereçleri sağlama şeklinde açıklanabilir. Buna göre öğretim gören bireyler, herhangi bir mesleği yerine getirebilmek için kendilerine gerekli olan bilgileri edinmeye çalışmaktadır. Bu açıklamalardan çıkarılabilecek sonuca göre eğitim beceri, öğretim ise bilgi ile yakından ilişkilidir. Bu ayrıma dayanarak eğitim programı ve öğretim programı ifadelerinin de değişik anlamları karşıladığı görülmektedir.

Eğitim programı, bireyde istenilen yönde davranış değişikliği meydana getirmek amacıyla yapılan bütün faaliyetleri önceden planlama çalışmalarıdır (Kılıç, 2003). Öğretim programı ise eğitim programında gösterilen kazanımların gerçekleşebilmesi için gerekli olan öğretmen, konular, eğitim ortamları, yöntem, teknik, fiziki imkânlar, ders araçları, ölçme ve değerlendirme gibi unsurları 


\section{Cumhuriyet Dönemi Türkçe Eğitimi ve Öğretimi Programlarında Yazma Becerisi}

kapsayan bir bütündür (Özbay, 2006: 14). Öğretim programı, öğrencilerden beklenen öğrenmeyi meydana getirebilmek için planlanmış faaliyetlerin tamamı olarak tanımlanabilir (Tekin 1991: 8). Öğretim programları, eğitim-öğretim çalışmaları içerisinde bir dersle ilgili faaliyetlerin öğrenme ve öğretme süreci içerisinde, nelerin, niçin ve nasıl yer alacağını ifade eden bir rehberdir (Girgin, 2011: 12). Bir başka deyişle öğretim programı, amaçlar ve bunları gerçekleştirecek konularla öğretmeni yönlendirecek düşünce ve etkinlikleri içermektedir. Türkiye'de eğitim-öğretim faaliyetleri, 1739 sayılı Millî Eğitim Temel Kanunu'na uygun olarak derslerin öğretim programları çerçevesinde yürütülmektedir.

Eğitim öğretim ortamlarının belirli ölçütlere göre geliştirilen programlara uygun bir şekilde yürütülmesinin önemi ve gerekliliği üzerine birçok görüş ortaya atılmıştır. Fer'e göre (2005: 3) öğretim programları, öğretim ve öğrenmeye ilişkin politika ve stratejilerin, kararların yaşama geçirilmesinde önemli bir araç durumundadır. Bu nedenle geçmişte olduğu gibi günümüzde de eğitimle ilgili olarak yürütülen çalışmaların temelinde eğitim ve öğretim programlarında yapılan düzenlemeler yer almaktadır. Balcı ve diğerleri (2012: 3) de programların bir öğretim alanının standart ve etkili bir süreç içinde gerçekleştirilmesinde önemli başlıklardan biri olduğunu vurgulamaktadır.

Genel olarak eğitim öğretim faaliyetlerinin programlı bir şekilde yürütülmesi gerektiği gibi öğrencilerin dinleme, konuşma, okuma ve yazma gibi dil becerilerinin gelişim süreci de aynı şekilde belirli programlara uygun olarak düzenli ve sistemli bir şekilde yürütülmelidir. İşeri (2007: 61) bu durumu "Dil becerilerinin geliştirilmesi, bireyin diğer derslerine ilişkin başarısını da etkileyebileceğinden dil öğretiminde kullanılacak yöntemlerin, araç ve gereçlerin amaca uygun biçimde seçilmesi ve öğretim ilkelerine uygun olarak ve dizgeli bir biçimde uygulanması gerekmektedir." şeklinde ifade etmektedir. Dil öğretiminin temel amaçları bireylere doğru, açık ve etkili bir iletişimi gerçekleştirmelerini sağlayacak becerileri kazandırmak; onların düşünme güçlerini geliştirmek ve toplumsallaşma süreçlerine katkıda bulunmaktır. Bu yüzden her millet, okullarında ana dilini öğretmek amacıyla programlar geliştirmektedir. Ana dili, bireyleri birbirine bağlayan, bir toplumu gelişigüzel insan yığını olmaktan çıkarıp milletleştiren en önemli etkenlerden biridir. Bu sebepledir ki her devirde toplumlar, kültürlerini yaşatabilmek ve gelecek kuşaklara aktarabilmek için ana dillerini toplumun bütün fertlerine öğretme gayreti içerisine girmişlerdir (Özbay ve Melanlıoğlu, 2009: 9). Bu yönüyle ana dili eğitimi ciddiyetle ele alınması, kültürel değerlerle beslenmesi gereken bir uygulama alanıdır.

Ana dili eğitimi anlama ve anlatma olmak üzere iki temel başlık altında yürütülen çalışmalarla gerçekleştirilmeye çalışılır. Anlama becerisi okuduğunu ve dinlediğini anlama, anlatma becerisi ise konuşarak ve yazarak anlatma becerisi şeklinde düşünülmektedir. Bireyin ana diliyle doğru, açık ve 
etkili bir iletişim kurabilmesi için dinleme, konuşma, okuma ve yazma becerilerinin bir bütün olarak geliştirilmesi gerekmektedir.

Temel dil becerilerinin en önemlilerinden birisi de kişiye, kendisini çevresine anlatabilme imkânı veren yazmadır. Yazma, insanoğlunun binlerce yıldır kullandığı en önemli iletişim yollarından biridir. Yazma becerisini kazanmak, bireyin hem günlük ihtiyaçlarını karşılaması ve eğitimini sürdürmesi hem de anlama ve anlatma yeteneğini yükselterek edebî eserlerden tat alabilmesi için gereklidir.

Yazmayı konuşma gibi sosyal bir gereksinim olarak gören Bülbül'e (2000: 2) göre yazııı anlatım bir fikrin, duygunun, düşüncenin ve görüşün ya da bir olayın anlamlı ve çekici yanlarını, yönlerini yazı yoluyla ifade etmektir. Özkırımlı (2002: 265) ise yazmayı, herhangi bir konuda duygu, düşünce ve izlenimlerin, o konuyla ilgili görüşlerin belli kurallara uygun olarak yazıyla anlatılması şeklinde tanımlamaktadır. Aktaş ve Gündüz'e (2002: 61) göre yazılı anlatım, her türlü olay, düşünce, durum ve duyguları, dili en güzel şekilde kullanarak, belli bir plan dâhilinde başkalarına ve yarınlara ulaştırmaya, böylece kalıcılığını sağlamaya imkân veren bir araçtır. Anlatma becerisi bakımından yerine getirdiği işlev ve bireye sunmuş olduğu imkân açısından oldukça önemli olan yazma becerisinin geliştirilmesi tesadüflere bırakılamaz. Yazma, ancak sistemli ve sürekli bir çalışmanın sonunda geliştirilebilir. Bu nedenle yazma becerisinin kazandırılmasına dönük etkinliklerin mutlaka planlı ve programlı bir şekilde yürütülmesi gerekmektedir. Bu çalışmada Cumhuriyet dönemi Türkçe eğitimi ve öğretimi programlarında yazma becerisinin amaçlar, açıklamalar, yöntem, davranış/kazanım ve düzeltme/değerlendirme başlıkları doğrultusunda nasıl planlandığı tespit edilmeye çalışılmaktadır.

\section{Yöntem}

\section{Araştırmanın Amacı}

$\mathrm{Bu}$ araştırmanın amacı, Cumhuriyet döneminde hazırlanmış ve uygulanmış olan Türkçe eğitimi ve öğretimi programlarında yazma becerisinin nasıl ele alındığını tespit etmektir.

\section{Alt Amaçlar}

Araştırmada yukarıdaki amaca bağlı olarak şu alt amaçlara ulaşılmaya çalışılımıştır:

1. Yazma becerisinin, Cumhuriyet döneminde hazırlanmış ve uygulanmış olan Türkçe eğitimi ve öğretimi programlarının "genel amaçlar" başlığı altında nasıl ele alındığını tespit etmek.

2. Yazma becerisinin, Cumhuriyet döneminde hazırlanmış ve uygulanmış olan Türkçe eğitimi ve öğretimi programlarının "açıklamalar" başlığı altında nasıl ele alındığını tespit etmek.

3. Yazma becerisinin, Cumhuriyet döneminde hazırlanmış ve uygulanmış olan Türkçe eğitimi ve öğretimi programlarının "yöntem" başlığı altında nasıl ele alındığını tespit etmek. 


\section{Cumhuriyet Dönemi Türkçe Eğitimi ve Öğretimi Programlarında Yazma Becerisi}

4. Yazma becerisinin, Cumhuriyet döneminde hazırlanmış ve uygulanmış olan Türkçe eğitimi ve öğretimi programlarının "davranış/kazanım" başlığı altında nasıl ele alındığını tespit etmek.

5. Yazma becerisinin, Cumhuriyet döneminde hazırlanmış ve uygulanmış olan Türkçe eğitimi ve öğretimi programlarının "düzeltme/değerlendirme" başlığı altında nasıl ele alındığını tespit etmek.

\section{Araştırmanın Modeli}

Bu araştırma nitel veri analizi tekniklerinden yararlanılarak gerçekleştirilen tarama modelinde betimsel bir çalışmadır. Tarama modeli, geçmişte ya da günümüzde var olan bir durumu, olduğu gibi betimlemeyi amaçlayan bir araştırma yaklaşımıdır. Araştırmaya konu olan olay, birey ya da nesne, kendi koşulları içinde ve olduğu gibi tanımlanmaya çalışıır. Onları herhangi bir şekilde değiştirme, etkileme çabası gösterilmez (Karasar, 2009: 77).

\section{Veri Toplama Teknikleri}

Araştırmada veri toplamak amacıyla doküman incelemesi kullanılmıştır. Doküman incelemesi, araştırılması hedeflenen olgu veya olgular hakkında bilgi içeren yazılı materyallerin analizini kapsar. Eğitim ile ilgili bir araştırmada ders kitapları, program yönergeleri vb. veri kaynağı olarak kullanılabilir (Yıldırım ve Şimşek 2008: 189). Araştırmada Cumhuriyet dönemi Türkçe eğitimi ve öğretimi programlarında yazma becerisine ne oranda yer verildiği incelenmiştir.

\section{Sınırlılıklar}

Araştırma şu sınırıııklar çerçevesinde gerçekleşmiştir:

1. Araştırma Cumhuriyet dönemi ortaokul/ilköğretim ikinci kademe Türkçe eğitimi ve öğretimi programlarıyla sınırlandırıımıştır. Bu bağlamda 1924 Lise Birinci Devre Müfredat Programı, 1929 Ortamektep Türkçe Programı, 1949 Ortaokul Türkçe Programı, 1981 İlköğretim Okulları Türkçe Eğitim Programı ve 2005 Türkçe Dersi (6, 7, 8. Sınıflar) Öğretim Programı yazma becerisi açısından değerlendirilmiştir. 1938 Ortaokul Türkçe Programı, 1929 Ortamektep Türkçe Programının "gramer" başlığı dışında hemen hemen aynısı olduğu; 1962 Ortaokul Türkçe Programı ise 1949 Ortaokul Türkçe Programına göre önemli değişiklikler içermediği için ayrıca değerlendirilmemiştir.

2. Araştırma, incelenen programların "genel amaçlar, açıklamalar, yöntem, davranış/kazanım, düzeltme/değerlendirme başıklarıyla sınırlandırılmıştır.

\section{Bulgular}

Çalışmanın bu bölümünde, Cumhuriyet dönemi Türkçe eğitimi ve öğretimi programlarında yazmaya ilişkin tespit edilen bulgulara yer verilmiştir. Bu bulguların sunumunda bazı ortak başlıklar esas alınmıştır. Bunlar; amaçlar (genel amaçlar, özel amaçlar), açıklamalar, yöntem, davranış/kazanım, düzeltme ve değerlendirme şeklindedir. Aşağıdaki tabloda çalışmada belirlenen başlıklar doğrultusunda Türkçe eğitim ve öğretim programlarının genel bir değerlendirmesi bulunmaktadır. 
Tablo-1 Türkçe Eğitim Öğretim Programları ve Genel Başlıklar

\begin{tabular}{|l|c|c|c|c|c|c|c|}
\hline & 1924 & 1929 & 1938 & 1949 & 1962 & 1981 & 2005 \\
\hline Amaçlar & & & & & & & \\
\hline a.Genel Amaçlar & - & $\mathrm{V}$ & $\mathrm{V}$ & $\mathrm{V}$ & $\mathrm{V}$ & $\mathrm{V}$ & $\mathrm{V}$ \\
\hline b.Özel Amaçlar & - & $\mathrm{V}$ & $\mathrm{V}$ & $\mathrm{V}$ & $\mathrm{V}$ & $\mathrm{V}$ & - \\
\hline Açıklamalar & $\mathrm{V}$ & $\mathrm{V}$ & $\mathrm{V}$ & $\mathrm{V}$ & $\mathrm{V}$ & $\mathrm{V}$ & $\mathrm{V}$ \\
\hline Yöntem & - & - & - & - & - & $\mathrm{V}$ & $\mathrm{V}$ \\
\hline Davranış/Kazanım & - & - & - & - & - & $\mathrm{V}$ & $\mathrm{V}$ \\
\hline $\begin{array}{l}\text { Düzeltme ve } \\
\text { Değerlendirme }\end{array}$ & - & - & - & $\mathrm{V}$ & $\mathrm{V}$ & $\mathrm{V}$ & $\mathrm{V}$ \\
\hline
\end{tabular}

Tablo 1'e göre, amaçlar başlığı 1924 Lise Birinci Devre Müfredat Programının dışındaki Türkçe eğitim öğretim programlarında; açıklamalar başığı bütün Türkçe eğitim öğretim programlarında; yöntem ile davranış/kazanım başlığı 1981 İlköğretim Okulları Türkçe Eğitim Programı ve 2005 Illköğretim Türkçe Dersi Öğretim Programlarında; düzeltme ve değerlendirme başlığı ise 1949 ve 1962 Ortaokul Türkçe Programı, 1981 Illköğretim Okulları Türkçe Eğitim Programı ve 2005 İlköğretim Türkçe Dersi Öğretim Programlarında ortak olarak yer almaktadır. Çalışmada tespit edilen beş ana başlık her programda bizzat yer almamıştır fakat programların satır aralarından çıkarılan bulgular da ilgili başlıklar altında değerlendirilmiştir.

1. Cumhuriyet Dönemi Türkçe Eğitimi ve Öğretimi Programlarının "Amaçlar" Başlığı Doğrultusunda Yazma Becerisi

\section{a. Genel Amaçlar}

Cumhuriyet dönemi Türkçe eğitimi ve öğretimi programlarına bakıldığında yazma becerisine yönelik ilk bulguların genel amaçlar bölümünde yer aldığı görülmektedir. Genel amaçlar başlığı 1929 Ortamektep Türkçe Programından itibaren 2005 Türkçe Dersi Öğretim Programına kadar bütün programlarda yer almıştır. Dolayısıyla bu programların hepsinde yazma becerisine ilişkin bilgi ve yönlendirmelere de rastlamak mümkündür.

Genel amaçlar başlı̆ı altında yazma becerisine yönelik ilk bilgiler 1929 Ortamektep Türkçe Programında "Ortamekteplerde Türkçe Derslerinin Başlıca Gayeleri " bölümünde yer almaktadır. Programda Türkçe derslerinin başlıca gayelerinden biri "Talebeyi meramını ağızdan ve yazı ile ifade etmeye alıştırmak." şeklinde belirlenmiştir. Buna göre Türkçe dersleri, öğrencinin öncelikle bilgi, duygu ve düşüncelerini yazılı bir şekilde ifade edebilmesini sağlamalıdır. Programda bu amaç cümlesinin açıklamasına da yer verilmiştir. Buna göre öğrencinin kendini yazılı olarak uygun bir şekilde ifade edebilmesi; "Yazacağı mevzunun icabına uygun bir şekilde mektup yazmak, muhtelif mevzulardan herhangi birisini vazı ve okunabilir bir şekilde kaleme almak, okuduğu bir parçanın veya edebî bir eserin en can alacak noktalarını hulâsa şeklinde tahlil ve ifade etmek, kendisini alâkadâr 
eden edebî, ilmî, ticarî bir mevzu üzerine tetkik ve tetebbübe bulunarak okuyanlara alâka verecek bir şekilde yazmak, küçük bir hikâye yazmak ve bazı münasip hikâyeleri "piyes" haline çevirmek" (Temizyürek ve Balcl, 2006: 233) gibi becerileri gerektirmektedir. Bu beceriler genelikle mektup, hikâye ve piyes gibi edebi türlerde yazı yazma; bir metni özünü korumak şartıyla özetleme; herhangi bir araştırma yaparak elde edilen sonuçları yazma; anlatılmak istenenleri açık ve anlaşılabilir bir şekilde yazıya aktarma gibi noktalarda toplanmaktadır.

Programın genel amaçlar bölümünde ayrıca öğrencinin yazılı anlatım sırasında dikkat etmesi gereken maddelere de yer verilmiştir. Öğrenci kendini yazılı olarak ifade ederken "Okunaklı ve pişkin bir yazı ile yazmaya; kelimelerin imlâsına; gramer ve sentaks kaidelerine uygun olarak yazmaya; büyük harfleri ve muhtelif nokta işaretlerini yerli yerinde kullanmaya; fikirlerini muvaffakiyetle ifade edebilmesi için çok kelimelere ve orijinal bir üslûba sahip olmaya; cümle ve paragrafların tanzim ve tertibinde muvaffakıyet göstermeye" (Temizyürek ve Balcı, 2006: 245)dikkat etmelidir.

Genel amaçlar başlı̆ı̆ altında yazma becerisine yönelik bilgiler içeren ikinci program, 1949 Ortaokul Türkçe Programıdır. Programın amaçlar bölümünde bulunan iki madde yazma becerisiyle doğrudan ilişkilidir. Bu maddeler, "Onlara gördüklerini, duyduklarını, bildiklerini, incelediklerini, öğrendiklerini, düşünüp tasarladıklarını söz ve yazı ile doğru olarak anlatma kudretini kazandırmak." ve "Dilimizin bağlı olduğu ana kuralları sezdirip öğreterek, onlara Türk dilini kullanmada güven sağlamak." (Temizyürek ve Balcı, 2006: 265) şeklindedir. Bunlardan birinci maddede, anlatılmak istenenlerin yazılı bir şekilde doğru olarak anlatılması üzerinde durulmaktadır. Íkinci maddede ise Türk dilinin güvenle kullanımı söz konusu edilmektedir. Dili kullanmanın iki boyutu vardır. Bunlar sözlü ve yazılı kullanımlardır. Buna göre Türk dilini güvenle kullanmak, zihinde tasarlanan mesajların sözlü ve yazılı olarak hedef kitleye ulaştırılmasıyla mümkündür.

1981 Illköğretim Okulları Türkçe Eğitim Programının genel amaçlar başlığı altında yazma becerisine yönelik iki madde bulunmaktadır. Bu maddeler "Onlara, görüp izlediklerini, dinlediklerini, okuduklarını, incelediklerini ve düşündüklerini, tasarladıkalrını söz ya da yazı ile doğru ve amaca uygun olarak anlatma beceri ve alışkanlığını kazandırmak; öğrencilere Türk dilini sevdirmek, kurallarını sezdirmek; onları, Türkçeyi gelişim süreci içinde bilinçle, özenle ve güvenle kullanmaya yöneltmek" (Temizyürek ve Balcı, 2006: 360) şeklindedir. Bu maddelerin bir önceki program olan 1949 programındakilerle çok benzediği görülmekedir. Birinci maddeye "amaca uygun olarak"; ikinci maddeye "Türk dilini sevdirmek, bilinçle, özenle kullanmaya yöneltmek" ifadeleri eklenmiştir.

2005 Türkçe Dersi Öğretim Programı, genel amaçlar bölümünde yazma becerisine yer veren son programdır. Kendisinden önceki iki program gibi bu programın da genel amaçlar bölümünde iki madde yazma becerisiyle doğrudan ilgilidir. "Duygu, düşünce ve hayallerini sözlü ve yazılı olarak etkili ve anlaşılır biçimde ifade etmeleri; Türkçeyi, konuşma ve yazma kurallarına uygun olarak bilinçli, doğru ve özenli kullanmaları." maddelerinde yazma becerisiyle ilgili bilgilere rastlanmaktadır. Bu iki 
maddenin 1949 programından itibaren 1981 ve 2005 programlarında bazı küçük değişikliklerle yinelendiği görülmektedir. Yani "genel amaçlar" bölümünde yazma becerisiyle ilgili olarak tespit edilen noktalar, aynı zamanda programların büyük ölçüde ortak noktalarını oluşturmaktadır.

\section{b. Özel Amaçlar}

Cumhuriyet dönemi Türkçe eğitimi ve öğretimi programlarında özel amaçlar başlığına 1924 Lise Birinci Devre Müfredat Programı ve 2005 İlköğretim Türkçe Dersi Öğretim Programı dışındaki tüm programlarda rastlamak mümkündür.

Özel amaçlar 1929 Ortamektep Türkçe Programında "Tahrir Derslerinin Gayesi" başlığı altında yer almıştır. Tahrir derslerinin gayeleri, "talebeye muhiti hakkında daha geniş bir alâka ve daha iyi bilgiler vermek, talebede müşahede ve bilgilerini tertip ve ifade kabiliyetini artırmak, iyi cümle, paragraf (fıkra) teşkili itiyadını inkişaf ettirmek, manasını kavrıyarak kullandığı kelimelerin adedini artırmak, en muvafık şekilde mektup yazmağı öğretmek, yazacağı kelimeleri yanlışsız yazmağı öğretmek, gramer ve sentaks kaidelerine muvafık olarak yazıya alıştırmak" (Temizyürek ve Balcı, 2006: 237) şeklinde sıralanmıştır.

Özel amaçlar bölümüne yer veren bir diğer program, 1949 Ortamektep Türkçe Programıdır. Bu programda özel amaçlar, "Söz ve Yaziyle ifade" ile "Imlâ" başlıkları altında ayrı ayrı yer almaktadır. Söz ve Yaziyle Anlatım başlığı altında "öğrencilere gördüğünü, yaşadığını, duyduğunu, tasarladığını, okuduğunu ve düşündügünü söz ve yaziyle doğru, maksada uygun ve güzel olarak anlatma yetisini kazandırmanın" (Temizyürek ve Balcı, 2006: 275) amaçlandığı ifade edilmiştir. İmlâ başlığı altında ise öğrencilere Türk dilindeki kelimelerin doğru yazıışını ve belli başlı imlâ kurallarını kavratmanın amaçlandığı belirtilmiştir.

1981 Ilköğretim Okulları Türkçe Eğitim Programına gelindiğinde özel amaçların Anlama ve Anlatım başlıkları altında ayrı ayrı yer aldığı görülür. Bunlardan "Anlatım" başlığı altında yazma becerisine ilişkin şu özel amaçlar belirlenmiştir. "Konunun gereğine göre türlü yapıdaki cümleleri doğru olarak kurabilme, yazım ve söz dizimi yanlışı yapmadan yazabilme, noktalama işaretlerini yerli yerinde kullanabilme, konuşmalarını ve yazılarını uygun bir plana göre geliştirebilme, Türkçe derslerindeki her türlü etkinliklere katılabilme, varılan sonuçları anlatabilme, açıklayabilme, gördükleri, bildikleri bir yeri, bir olayı, bir canlıyı, bir kimseyi vb. anlatabilme, tanıtabilme, bunlar hakkında duygu ve düşüncelerini açıklayabilme, okunan bir kitap, dinlenen müzik parçası, gezilen bir sergi, izlenen bir film, bir oyun, bir maç vb. üzerine açıklamalarda, eleştirmelerde bulunabilme; yargıya varabilme, türlü konularda tasarladıklarını ve düşündüklerini anlatabilme (ileriki öğrenimi ya da hayatı, yurt ve dünya sorunları ile ilgili), toplantı programlarını düzenleyebilme, kararlarını yazabilme, bu konularda bildiriler, duyurular hazırlayabilme, sonuçları rapora bağlayabilme, kelime grupları, atasözü, özdeyiş, deyim, vb.ni açıklayabilme, çeşitli derslerle ilgili açıklama ve bu raporları 
saptayabilme, özet çıkarabilme, not alabilme, günlük hayatta geçerli yazışmaları yapabilme, sözlü ve yazılı sanat etkinliklerine katılabilme, varsa bu alanlardaki yeteneklerini geliştirebilme, her zaman, her türlü kalemle okunaklı, işlek, güzel ve düzenli bir el yazısıyla yazabilme beceri ve alışkanlıklarını kazandırma" (Temizyürek ve Balcı, 2006: 272). Bu maddelerden öğrencilerin yazııı anlatım çalışmalarında hem şekil hem de içerik olarak bazı beceriler kazanmalarının ön görüldüğü çıkarılmaktadır. Doğru cümleler kurma, yazım kurallarına ve noktalama işaretlerine uyma gibi beceriler bu etkinliğin şekil yapısına; bildiri, duyuru, rapor yazabilme, özet çıkarma, not alma, günlük yazışmaları yapabilme gibi maddeler ise yazmayı günlük hayatı daha kolay ve pratik bir hale getirmeye yöneliktir. Buradan hareketle yazma etkinliklerinin öğrencinin günlük hayatta karşıllaştığı problemlerin çözümüne destek olacak şekilde yürütülmesi gerektiği şeklinde bir yorum yapılabilir.

2. Cumhuriyet Dönemi Türkçe Eğitimi ve Öğretimi Programlarının “Açıklamalar” Başlığı Doğrultusunda Yazma Becerisi

Cumhuriyet dönemi Türkçe eğitimi ve öğretimi programlarında açıklamalar niteliğindeki ilk bilgiye, 1924 Lise Birinci Devre Müfredat Programında yer alan Lise Müfredat Programlarının Esbâb-ı Mûcibe Lâyihası kısmında rastlıyoruz. Bu bölümde yazma eğitimiyle ilgili olarak "Tahrir mevzuları hayattaki ihtiyaçlara tekabül etmelidir. Çocuk, şahsi müşahedeleriyle yazı hazırlamakta serbest olmalıdır. Mamafih muallimin esasını, hududunu çizerek vazife vermesi icap eder. Tahrir dersleri yine talebenin müşahede ve tassüslerine, muallimin vereceği esas, hudud muayyen mevzulara ait olmak üzere mütekamilen devam etmelidir" (Temizyürek ve Balcı, 2006: 231) ifadelerine yer verilmiştir.

Tahrir mevzuları hayattaki ihtiyaçlara tekabül etmelidir ifadesindeki amacın, yazma sürecinde kazanılacak becerilerin gerçek yaşama uygulanmasını kolaylaştırmak olduğu yorumu yapılabilir. Çocuk, şahsi müşahedeleriyle yazı hazırlamakta serbest olmalıdır, mamafih muallimin esasını, hududunu çizerek vazife vermesi icap eder ifadelerinden ise, öğrencinin deneyim ve birikimlerinden yola çıkarak yazacağı, öğretmenin bu sürece hudud çizerek, esas belirleyerek rehberlik edip, öğrenciyi yönlendireceği çıkarılabilir.

1929 Ortamektep Türkçe Programında yazılı anlatım etkinliğiyle ilgili açıklamalara "Umumî Mülahazalar" başlığı altında yer verilmektedir. Bu kısımda yazma becerisi doğrultusunda "Türkçe dersleri lisanın şifahi ve tahriri cephesini mütevazi olarak ilerletmelidir. Talebe lisanın yalnız tahriri cephelerinde iyi itiyatlar kazanmış olmakla onları şifahi cephede de mutlaka kazanmış sayılmazlar. Şifahi cepheye de ayrıca itina etmek zarureti vardır." (Temizyürek ve Balcı, 2006: 236) ifadelerine yer verilmiş̧ir. Buna göre bir iletişim aracı olan dilin sözlü ve yazılı olmak üzere iki boyutu vardır. Türkçe dersleri dilin hem sözlü hem de yazılı yönünü her birine aynı derecede önem vererek geliştirmeye çalışmalıdır. Çünkü öğrencinin dilin yazılı yönünü iyi bir şekilde kullanması, aynı zamanda sözlü ifadeyi de iyi bir şekilde kullandığı anlamına gelmez. Burada anlatım etkinliğine sözlü ya da yazılı boyuttan 
herhangi birinin ağırlığında bakılmadığı, anlatım becerilerinin bir bütün olarak görüldüğg̈ ve birlikte geliştirilmesi gerektiği üzerinde durulmaktadır.

1949 Ortaokul Türkçe Programında yazılı anlatım becerisine yönelik açıklamalara birkaç başlık altında ve her bir başlığın kendisiyle ilgisi ölçüsünde yer verilmiştir. Bu başlıklar "Genel Olarak Söz ve Yaziyle ifade", "Yaziyle ifade" ve "Imla" şeklindedir.

"Genel Olarak Söz ve Yaziyle ifade" başlığı altında ilk olarak yazılı anlatımın işlevine değinilmiştir. Buna göre yazılı anlatımın işlevi, "sözün zaman ve mekân içinde yayılmasını sağlıyan tek araç" olmasından kaynaklanmaktadır. Bu nedenle yazma çalışmalarına işlevine uygun bir değer ve önem vermek gerekir. Bunun için "öğretmen, bir yandan öğrencilerinin meramlarını sözle ifade etmelerine imkân verirken bir yandan da yazılı anlatmaya imkân ve fırsatlar hazırlamalı, bu yeteneklerin ilk okuldakine üstün bir şekilde gelişmesini sağlamalıdır." (Temizyürek ve Balcı, 2006: 275).

Bu başlık altında ikinci olarak yazma çalışmalarının hayatla iç içe olması gerektiği üzerinde durulmaktadır. Buna göre öğrenci; "okunan bir makale, dinlenen bir konferans, seyredilen bir müsamere gibi yazılı ifadesinin içeriğini destekleyebilecek hayat olaylarını incelerken birçok izlenim alır. Bu izlenim, gözlem ve bilgileri düzenli bir sıra içinde tertiplemek, başkalarına söz veya yazı ile nakletmek de söz ve yazı ile ifade amacının sınırları içine girmektedir. Bu şekilde geliştirilen Türkçe dersleri hayati değerlere daha çok önem veren ve çocuğa muhitini daha iyi tanıtmakta etken olan bir öğrenim sağlıyacaktır." (Temizyürek ve Balcı, 2006: 275).

"Genel Olarak Söz ve Yaziyle ifade" başlı̆ı altında yapılan açıklamaların sonuncusu dil ve anlatım özellikleriyle yani üslupla ilgilidir. Öğrenci yazılı anlatım çalışmalarını yürütürken dil ve anlatım açısından aşamalı bir yol izlemelidir. Öncelikle herhangi bir konu hakkındaki bilgi, duygu ve düşüncelerini doğru, açık ve anlaşılır bir şekilde anlatabilme becerilerini kazanmalıdır. Yazma çalışmalarında ilerledikçe öğrenci kendi şahsi üslubunu oluşturabilir. Bu nedenle aşamalı olarak doğru, anlaşılır bir anlatımdan şahsi, edebî üslup sahibi olmaya yönelik bir sıralama izlenmelidir. Öğrencide bunun aksi yönünde bir eğilim varsa, öğretmen onu uyarmalı, süslü ve ağdalı bir ifadeden önce fikirlerini düzgün bir şekilde ifade etmeye alıştırmalıdır. Bu durum programda "Söz ve yazıı ifadede önem verilecek bir diğer nokta da çocuğun süslü ve üsluplu ifadeye, doğru ve düzgün anlatımdan daha çok değer vermesini önlemektir. Öğrenci, bir üslup endişesinden evvel fikrini en kısa ve akla en yakın yoldan anlatabilmeye alışmalı; öğretmen, gereksiz benzetmelere, kelime oyunlarına, edebiyat yapma özentilerine göz yummamalıdır." şeklinde ifade edilmektedir (Temizyürek ve Balcı, 2006: 275).

1949 Ortaokul Türkçe Programında "Yaziyle ifade" başlığı altında yer alan açıklamalar genel hatlarıyla yazma ödevleri, yazma becerisinin işlevi, yazma cesareti, dil ve anlatım özellikleriyle ilgilidir. Programda yazma ödevleri bağlamında dil becerilerine bütüncül bir bakış açısı gündeme 


\section{Cumhuriyet Dönemi Türkçe Eğitimi ve Öğretimi Programlarında Yazma Becerisi}

getirilmektedir. Buna göre "Kompozisyon ödevlerinin; çeşitli yerlerdeki çalışmalarıyla; Türkçe öğreniminin okuma, söz ve yaziyle ifade, dil bilgisi ve imla gibi hemen bütün bölümlerinde başarı sağladığı unutulmamalı ve bu derse önem verilmelidir." (Temizyürek ve Balcı, 2006: 278). Dil becerilerinden herhangi birinde meydana gelen bir gelişme, diğer becerilerin gelişiminde de olumlu bir etki yapmaktadır. Bu doğrultuda yazma alanında sağlanan gelişmeler, okuma, sözle ifade, imla ve dil bilgisi alanları için de önem taşımaktadır.

Yazma çalışmalarının bir diğer işlevi ise psikolojik yönde kendini göstermektedir. Yazma çalışmaları öğrencilerin şahsiyet gelişimleri üzerinde etkili bir role sahiptir. Öğrenci yazma çalışmalarında ilerledikçe gözlem ve hayata dair deneyimini artırır, farklı tür ve konularda okumalar yapar, olayları ve durumları daha geniş bir bakış açısıyla değerlendirerek kendi yargı ve kanaatlerini oluşturur. Bu süreç, onun kişilik gelişimi için oldukça önemlidir. Yazma çalışmalarının bu işlevi unutulmamalı ve "öğrenciye gördüğünü, yaşadığını, duyduğunu, tasarladığını, okuduğunu ve düşündügünü yaziyle doğru, düzgün, maksada uygun ve güzel olarak yazmak yetki ve cesareti kazandırmalıdır." Bu amaçla "gözlem yeteneğinin, tertip ve anlatış kabiliyetinin geliştirilmesine, anlamını kavrıyarak kullandığı kelimelerin sayısını çoğaltmasına, kelime, cümle ve fikirleri yanlışsız olarak tertiplemeyi öğrenmesine, imla kurallarını uygulama alışkanlığını kazanmış bulunmasına dikkat etmek lazımdır." (Temizyürek ve Balcı, 2006: 278).

"Yaziyle İfade" başlı̆ı altındaki açıklamalardan biri de verici dil becerileri olarak bilinen sözlü anlatım ve yazılı anlatım arasında ilgi kurmaya dayanmaktadır. Buna göre "düzgün yazmak, her şeyden önce düzgün konuşmakla sıkı bir surette ilgilidir. Bu sebeple, sözle ifade alıştırmaları öğrencilerin düzgün konuşmaları için olduğu kadar, düzgün yazmaları için de faydalı bir başlangıç olur." (Temizyürek ve Balcı, 2006: 278). Burada herhangi bir konu hakkında yazma çalışmasına başlamadan önce, konuyla ilgili sözlü anlatım çalışmaları yapmanın, konu ile ilgili bilgi ve düşünceleri öncelikle konuşarak ortaya koymanın önemine değinilmektedir. Böyle bir uygulama, konu hakkında hiçbir ön bilgiye sahip olmayan öğrencilerin de bilgilenmesini sağlayacağından, yazma planııın yapılmasını ve bu planın yazma uygulamasına dönüştürülerek bir metin elde edilmesini kolaylaştıracaktır. Bu düşünce programda “öğrencilere yazmanın, söylenenlerin tesbitinden başka bir şey olmadığı, ancak yazının konuşmaktan daha düzgün olduğu ve kaybolmayarak kaldığı hatırlatılmalı ve yazma işi sık sık konuşmalara bağlanmalıdır." şeklinde desteklenmektedir.

Bu başık altındaki açıklamalardan bir diğeri dil ve anlatım özellikleri üzerine yapılmaktadır. Bu bağlamda öğrencilerin, yazılarını sade ve samimi bir dille oluşturmaları, hakkında yazı yazmaya çalıştıkları konunun özelliklerine uygun bir üslup kullanmaları gerektiği hatırlatılmaktadır. Öğretmen, yazma çalışmalarını dikkatle izlemeli ve "öğrencilerde, suni bir dille yazma heves ve itiyadı başlıyorsa onu sade ve samimi bir dile çevirmek, yazdıkları yazılarda kullandıkları üslubu konuya uydurmak hususlarında orta okul öğreniminin ilk zamanlarından itibaren titiz davranmalıdır." Bu şekilde 
öğrencilerin meramlarını düzgün bir şekilde ifade etmelerini sağlamak gerekir. Programda ayrıca öğrencilerin meramlarını düzgün bir şekilde ifade edebilmeleri için kazanmaları gereken alışkanlıklara da yer verilmiştir. Buna göre öğrenciler yazarken konudan ayrılmamalı; bir konu hakkındaki fikirlerini birkaç paragraf halinde doğru bir şekilde ifade edebilmeli; okunan bir metni, ana hatlarını korumak şartıyla yazılı olarak özetleyebilmeli; herhangi bir konuda araştırma yaparak ulaşılan sonuçları düzgün bir şekilde yazıya aktarabilmeli; küçük hikâyeler yazabilmelidir.

"Yaziyle Ifade" başığı altında son olarak yazma şahsiyeti kavramıyla karşılaşılmaktadır. Programa göre yazma şahsiyeti kavramı, öğrencilerin yazmaya eğilimli oldukları alanları ifade etmektedir. Bunlar başlıca beş grupta toplanmaktadır. Tasvirci tip, yazma sırasında daha çok gördüğünü, izlediğini, incelediğini ayrıntılı bir şekilde betimlemeye eğilimlidir. Gözlemci tip, tek tek görülen olaylar arasında münasebetler aramaya eğilimli iken duygucu tip, daha çok kendi duygularını ifade etmekten hoşlanır ve şiir türüne yakındır. Bilimci tip, araştıma-sorgulama sonunda ulaştığı bilgiler arasında münasebet kurmaya çalışır. Son olarak muhayyileli tip, yazarken hayal dünyasını kullanır ve roman, hikaye gibi türlerde karşılaşılan gerçeğe benzer bir dünya yaratır. Burada öğretmene düşen görev, öğrencilerin yazma şahsiyetlerini belirlemek ve onların yazma eğilimlerine (şahsiyetlerine) uygun yazma konuları vermektir.

1949 Ortaokul Türkçe Programının "Imla" başlığı altındaki açıklamalar kısmında, imla yanlışlarının hangi sebeplerden kaynaklanabileceği ve bunların nasıl düzeltilebileceği üzerinde durulmuştur. Buna göre imla yanlışları, dikkatsizlikten, ağız farklarından, unutmaktan, yanlış teleffuzdan, kelimenin daha önce yazılış şeklinin görülmemesinden kaynaklı olabilir. İmla yanlışları düzeltilirken sadece kuralların söylenilmesiyle kalınmayıp cümle örnekleriyle ugulamaların da yapılması gerektiği hatırlatılmaktadır. Ayrıca imla yanlışlarının ya okulda ya da okul dışında düzeltilebileceğinden bahsedilmiştir. İmla yanlışları okulda kendi kendine, öğretmen veya sınıf tarafından düzeltilebilirken okul dışında yine öğrencinin kendi kendine veya öğretmenin düzeltip geri vermesi suretiyle yerine getirilebilir.

1981 İlköğretim Okulları Türkçe Eğitim Programının "Açıklamalar" bölümünde yazma becerisine geniş bir yer verilmektedir. Bu başlık altında yazma becerisi öncelikle karşılıklı anlaşmayı sağlaması yönüyle ele alınmaktadır. Buna göre insanların birbirleriyle anlaşabilmelerinin iki yönü vardır. Birincisi söylenenleri, okunanları anlamak ikincisi ise bilgi, duygu, düşünce ve tasarıları sözle ya da yazı ile anlatmaktır. Çağımızdaki toplumsal yaşayış, demokratik düzen, başkalarını anlama kadar, kendimizi anlatmamızı da zorunlu kılmaktadır. Bu noktada yazılı anlatım, sözlü anlatıma göre bazı farklılıklar göstermektedir. Yazıda her şeyi önceden iyice hesaplayarak, yazımızı okuyacak kimsenin düşünce ya da duygularımızı tam bizim istediğimiz biçimde anlamasını sağlayıcı önlemleri önceden almamız gereklidir. Çünkü, yapacağımız yanlışları sonradan şu ya da bu biçimde düzeltemez, eksiklikleri tamamlayamayız. Ayrıca yazılı anlatımın belli ve kesin kuralları vardır. Yazı yazarken 
bunlara uymamız, düşüncelerimizi kurallara uygun cümleler durumuna getirmemiz, bu cümleleri en etkili ve amacımıza en iyi varacak biçimde sıralamamız gerekir. Bunun içindir ki, yazma öğretimi ve yazılı anlatım, öteden beri Türkçe dersinin en önemli etkinliklerinden biri olagelmiştir; böyle olmayı da sürdürecektir.

Programın açıklamalar başlığı altında yazma becerisi "Türkçeyi doğru olarak, bilinçle ve güvenli kullanmayı alışkanlık haline getirmenin en etkili yollarından biri" olarak değerlendirilmektedir. Öğretmen, derslerde öğrencilere sık sık düşüncelerini sözlü ve yazılı olarak anlatma imkân ve koşullarını sağlar, onları ne kadar çok konuşturur, yazdırırsa kendilerini doğru, açık ve anlaşıır bir şekilde ifade etme noktasında olumlu sonuç almayı o kadar kolaylaştırmış olur.

2005 Türkçe Dersi (6. 7. 8. Sınıflar) Öğretim Programında yazma becerisi ile ilgili açıklamalar "Temel Dil Becerileri" başlığı altında yer almaktadır. Burada ilk olarak yazma becerisinin "işlev"inden bahsedilmektedir. Buna göre yazılı anlatım, bireyin kendini doğru ve amacına uygun olarak ifade etmesinde ve iletişim kurmasında en etkili araçlardan biridir. Türkçe Öğretim Programında yazma becerisinin geliştirilmesiyle; öğrencilerin duygu, düşünce, hayal, tasarı ve izlenimlerini dilin imkânlarından yararlanarak ve yazılı anlatım kurallarına uygun şekilde anlatmaları, yazmayı kendini ifade etmede bir alışkanlığa dönüştürmeleri ve yazma yeteneği olanların bu becerilerini geliştirmeleri amaçlanmaktadır. Programın temel dil becerileri başlığı altında yazma becerisinin diğer dil becerileriyle ilgisine de değinilmiştir. Yazma becerisinin bilgi, birikim ve dili etkili kullanmayı gerektirdiği göz önüne alınarak bu sürecin dinleme/izleme, konuşma, okuma ve dil bilgisi etkinlikleriyle de desteklenmesi gerekmektedir.

3. Cumhuriyet Dönemi Türkçe Eğitimi ve Öğretimi Programlarının "Yöntem" Başlığı Doğrultusunda Yazma Becerisi

Cumhuriyet dönemi Türkçe eğitimi ve öğretimi programlarında "Yöntem" başlığına müstakil olarak 1981 İlköğretim Okulları Türkçe Eğitim Programı ile 2005 Türkçe Dersi Öğretim Programında yer verilmiştir. Diğer programlarda doğrudan yöntem başlı̆̆ı altında olmasa da yönteme ilişkin yani yazılı anlatım çalışmalarının nasıl yürütülmesi gerektiğiyle ilgili bazı satır arası bilgilere rastlamak mümkündür.

1924 Lise Birinci Devre Müfredat Programının "Türkçe Programının Esbab-ı Mûcibesi” başlığı altında yönteme ilişkin ilk bilgi bulunmaktadır. Buna göre "Tahrir mevzuları hayattaki ihtiyaçlara tekabül etmelidir. Çocuk, şahsi müşahedeleriyle yazı hazırlamakta serbest olmalıdır." (Temizyürek ve Balcı, 2006: 231) Burada iki önemli nokta bulunmaktadır. Birincisi öğrencilere yazmak için verilen konuların öğrencilerin günlük hayatta karşılaştığı olay, durum vb. ile ilgili olması; ikincisi ise öğrencilerin yazılarını somut gözlemlerinden hareketle oluşturmalarıdır. Yani yazılı anlatım çalışmalarının mutlaka günlük hayatta karşılığı bulunmalıdır. 
1929 Ortamektep Türkçe Programında da yazılı anlatım çalışmalarının nasıl yürütülmesi gerektiğine yönelik bazı bilgiler vardır. Programa göre Tahrir mevzuları verilirken talebenin onları yazması için içtimaî bir saik bulunması çok faydalı olur. Meselâ talebenin hakikaten hasta olan arkadaşlarına hatır sormak için mektup yazmaları böyle içtimaî bir saik üzerine yazı yazmaları demektir. Mektubu muhayyel bir hastaya yazdırmadansa sırası gelince talebenin alâkadar oldukları bir hastaya yazdırmak daha terbiyevîdir." Ayrıca "yazdırılacak mevzular üzerine bazan evelce şifahî mükâleme yapmak ve bu mükâleme üzerine plân çizmek faydalıdır." (Temizyürek ve Balcı, 2006: 239). Burada ifade edilmek istenen yöntem bilgisi 1924 Programı́nın benzeri ve devamı niteliğindedir. 1929 Programı'nda da yazılı anlatım çalışmaları için seçilen konuların mutlaka günlük hayatta bir karşılığının bulunması gerekmektedir. Ancak bu şekilde öğrenciler gerçek hayata hazırlık yapmış olabilirler. Yazııı anlatım çalışmaları yürütülürken dikkat edilmesi gereken başka bir nokta da hemen yazmaya başlamak yerine öncelikle konu hakkında sözlü olarak görüş alışverişinde bulunmak daha sonra bir ön bilgi ile yazmaya başlamaktır. Bu çalışma günümüzde uygulanmakta olan güdümlü yazma etkinliklerini hatırlatmaktadır.

1949 Ortaokul Türkçe Programındaki yönteme ilişkin bilgiler de genellikle yazma konularının seçimi ve işlenmesi üzerine kurulmuştur. Buna göre "ilk sınıfların yazma konularında somuttan başlıyarak soyuta doğru gidilmeli, evvela yaşanmış konuların hazırlanmasına önem verilmelidir. Mesela çocuk ruhuna ait olaylar; korkuların, heyecanların, izlenimlerin, sevinçlerin, üzüntülerin, çekilen bir hastalığın, uğranılan bir haksızlığın, görülen bir cezanın, rüyaların yazılması gibi." (Temizyürek ve Balcı, 2006: 281). Bu konulara bakıldığında genel olarak eğitim ilkelerinden ikisine rastlanmaktadır. Bunlar somuttan soyuta ilkesi ile bilinenden bilinmeyene ilkesidir. Öğrenciler öncelikle yakın çevrelerinden bizzat gözlemledikleri somut konular hakkında yazacaklar daha sonra gelişimlerine paralel olarak soyut konular üzerinde çalışmaya başlayacaklardır. "Öğrencinin bildiği, yaşadığı ve kavradığı olaylar, anlamaya başladığı gerçekler, okul, sınıf, mahalle, arkadaş tip ve karakterlerinin tasviri, ilk yazma denemelerinin tabii konularıdır." (Temizyürek ve Balcı, 2006: 281). ifadesi de yukarıdaki görüşü destekler niteliktedir.

Yazma konularının tespitinde gözetilecek başka bir eğitim ilkesi de öğrenciye görelik ilkesidir. Buna göre "Yazma konuları öğrencinin hoşlanacağı nitelikte olmalıdır. Onlar, yalnız büyüklere zevk veren, sadece akıl, mantık veya nasihat ihtiva eden, mutlaka ahlakî telkinlerle sonuçlanan mevzulardan ziyade, bu amaçları hareketli, konuşmalı hikayelerle sağlıyan konulardan hoşlanırlar." (Temizyürek ve Balcı, 2006: 281). Öğrenciye akıl ve nasihat veren, içeriğinde öğüt barındıran kuru konular yerine, olay içeren ve macera ağırıklı konular tercih edilmelidir. Yazma çalışmalarının nasıl yürütüleceğine ilişkin başka bir bilgi de ortaokul sınıflarından itibaren serbest yazma çalışmalarına ağırlık verilmesi gerektiğidir. Serbest yazma çalışmaları öğrenciye sağladığı yaratıcılık ve düşündürücülük açısından oldukça faydalıdır. Öğrencilerin özel yeteneklerinin belirmesinde ve yazma 


\section{Cumhuriyet Dönemi Türkçe Eğitimi ve Öğretimi Programlarında Yazma Becerisi}

şahsiyetlerinin ortaya çıkarılmasında serbest yazma çalışmalarının önemli bir yeri vardır. Bu nedenle serbest yazma çalışmalarına sınıf içinde ve sınıf dışında mutlaka zaman ayrılmalıdır.

1981 İlköğretim Okulları Türkçe Eğitim Programında kendinden önceki programlardan farklı olarak müstakil bir "Yöntem" başlığı bulunmaktadır. Bu başlık altında okuma parçalarının nasıl işlenmesi gerektiğine, anlatım çalışmalarına, dil bilgisi etkinliklerinin yürütülmesine ilişkin bilgiler vardır. Bu bölümde yazma etkinliklerine "Anlatım Çalışmaları" başlığı altında değinilmiştir.

1981 programının yazma çalışmalarının yürütülmesine ilişkin ilk yönlendirmesi, bu çalışmalar için ayrı bir ders saatinin beklenmemesi gerektiğidir. Yazılı anlatım çalışmaları, anlama etkinliğinden normal bir akış sağlanarak başlatılmalı; dersin bölünmemesi sağlanarak hem anlama hem de anlatma etkinlikleri eşgüdüm içinde yürütülmelidir. Dolayısıyla metin çözümlenirken aynı zamanda anlatım etkinliğinin içinde bulunulduğu unutulmamalı, anlama ve anlatma etkinliği iç içe kaynaştırılarak yürütülmelidir.

Yazılı anlatım çalışmalarının yürütülmesinde ikinci önemli nokta, bu çalşmaların metinden hareketle yaptırılması, kuru, herhangi bir amaca hizmet etmeyen anlatım etkinliklerinden uzak durulmasıdır. Buna göre "Soru sorarken, konu çözümlenirken, sorulara karşılıklar alınırken dil ve anlatım özelliklerine yön verilmeli, sözlü ve yazılı anlatım etkinliğinde de metinden hareket etme, bu etkinlikleri iç içe kaynaştırılmış olarak verme sağlanmalıdır." (Temizyürek ve Balcı, 2006: 394).

Bu bölümde yazılı anlatım çalışmaları ile dil bilgisi etkinlikleri arasındaki ilişkiye de değinilmiştir. Dil bilgisi, anlamada olduğu gibi anlatımda da bir araç olarak kullanılmalıdır. Dil bilgisi konuları, güzel ve doğru yazı yazmaya hizmet etmeli, uygulamalı olarak öğretilmeye çalışıımalıdır.

2005 Türkçe Dersi (6-8. Sınıflar) Öğretim Programında diğer dil becerilerinde olduğu gibi yazma becerisine yönelik yöntemlere yer verilmiştir. Bu yöntemlerin amacı genel olarak öğrencilerin hangi alanlarda ve türlerde yazma yeteneklerinin olduğunu belirlemek ve onları uygun yazma yöntem ve türlerine yönlendirmektir. Programda yazmaya yönelik önerilen yöntemler ve bu yöntemlerin amaçları aşağıdaki tabloda gösterilmektedir: 
Tablo 2. 2005 Türkçe Dersi (6-8. Sınıflar) Öğretim Programında Yer Alan Yazma Yöntemleri

\begin{tabular}{|c|c|}
\hline Yazma Yöntemi & Amaç \\
\hline Not Alma & $\begin{array}{l}\text { Öğrencilerin okunan veya dinlenilenlerin önemli noktalarını seçebilmesini, bilgi ve } \\
\text { düşüncelerini sınıflandırabilmesini ve sistemli çalışma becerisini kazanmalarını } \\
\text { sağlayarak zaman kaybını önlemek }\end{array}$ \\
\hline Özet Çıkarma & $\begin{array}{l}\text { Öğrencilerin okuduklarını, dinlediklerini/izlediklerini anlamalarını ve anladıklarını, } \\
\text { konunun/metnin bağlamına uygun olarak anlatma becerilerini geliştirmek }\end{array}$ \\
\hline Boşluk Doldurma & $\begin{array}{l}\text { Öğrencilerin anladıklarını kısa ve öz bir şekilde anlatma becerilerini geliştirmek, } \\
\text { onlara bilinçli ve düzenli çalışma alışkanlığı kazandırmak }\end{array}$ \\
\hline Kelime ve Kavram & Öğrencilerin öğrendikleri kelime, kavram, atasözü ve deyimleri anlatımlarında \\
\hline $\begin{array}{c}\text { Havuzundan Seçerek } \\
\text { Yazma }\end{array}$ & kullanmalarını sağlayarak kalıcı kılmak ve böylece söz varlıklarını zenginleştirmek \\
\hline Serbest Yazma & $\begin{array}{l}\text { Öğrencilerin herhangi bir konudaki duygu, düşünce ve hayallerini yazmalarını } \\
\text { sağlayarak ifade güçlerini ve yazılı anlatım yeteneklerini geliştirmek }\end{array}$ \\
\hline Kontrollü Yazma & $\begin{array}{l}\text { Kelimelerin, cümle yapıları ve ifade kalıplarının Türkçenin kurallarına uygun şekilde } \\
\text { yazılmasını sağlamak }\end{array}$ \\
\hline Güdümlü Yazma & $\begin{array}{l}\text { Öğrencilerin bir konu hakkındaki bilgilerini, duygularını ve düşüncelerini etkili bir } \\
\text { şekilde anlatma becerilerini geliştirmek }\end{array}$ \\
\hline Yaratıcı Yazma & Öğrencilerin yazma yeteneklerini ve yaratıcılıklarını geliştirmek \\
\hline Metin Tamamlama & $\begin{array}{l}\text { Öğrencilerin okuduklarından hareketle duygu, düşünce ve hayal dünyalarını } \\
\text { zenginleştirmek, onları etkin duruma getirerek yorum yapma ve fikir yürütme } \\
\text { becerilerini geliştirmek }\end{array}$ \\
\hline Tahminde Bulunma & $\begin{array}{l}\text { Öğrencilerin okuduklarından hareketle duygu, düşünce ve hayal dünyalarını } \\
\text { zenginleştirmek, onları etkin duruma getirerek yorum yapma ve fikir yürütme } \\
\text { becerilerini geliştirmek }\end{array}$ \\
\hline Bir Metni Kendi & Öğrencilerin kendilerine özgü ifade şekillerini ve üslûplarını geliştirmek \\
\hline $\begin{array}{c}\text { Kelimeleriyle Yeniden } \\
\text { Oluşturma }\end{array}$ & \\
\hline $\begin{array}{l}\text { Bir Metinden Hareketle } \\
\text { Yeni Bir Metin Oluşturma }\end{array}$ & $\begin{array}{l}\text { Öğrencilerin hangi türde yazmaya yatkın olduklarını belirleyerek yaratıcılıklarını o } \\
\text { yönde geliştirmek }\end{array}$ \\
\hline $\begin{array}{l}\text { Duyulardan Hareketle } \\
\text { Yazma }\end{array}$ & Öğrencilerin algılama güçlerini ve dikkatlerini geliştirmek \\
\hline Grup Olarak Yazma & $\begin{array}{l}\text { Öğrencilerin çevreleriyle iletişim kurmalarını, iş birliği yapmalarını ve birbirleriyle } \\
\text { etkileşimde bulunarak grup bilinci kazanmalarını sağlamak, böylece kişisel } \\
\text { gelişimlerine yardımcı olmak }\end{array}$ \\
\hline Eleştirel Yazma & $\begin{array}{l}\text { Öğrencilerin olay ve durumlara tarafsız bakma, yorum yapma, fikir ve çözüm } \\
\text { üretme becerilerini geliştirmek }\end{array}$ \\
\hline
\end{tabular}

\section{Cumhuriyet Dönemi Türkçe Eğitimi ve Öğretimi Programlarının "Davranış/Kazanım”}

\section{Başlı̆ı̆ Doğrultusunda Yazma Becerisi}

Cumhuriyet dönemi Türkçe eğitimi ve öğretimi programlarında öğrencilerin yatay olarak her sınıf düzeyinin sonunda, dikey olarak da 8. sınıfın sonunda edinmeleri gereken bilgi, beceri ve alışkanlıklar toplamı olan özellikler ilk olarak 1981 ilköğretim Okulları Türkçe Eğitim Programında "Öğrencilerin Kazanacakları Davranışlar"; 2005 Türkçe Dersi Öğretim Programında ise "Amaç ve Kazanımlar" başlığı altında yer almıştır. Ayrıca "davranış" ya da "kazanım" şeklinde bir başlık altında olmasa da bu anlamda değerlendirilebilecek maddelere ilk olarak 1949 Ortaokul Türkçe Programında rastlanmaktadır. 


\section{Cumhuriyet Dönemi Türkçe Eğitimi ve Öğretimi Programlarında Yazma Becerisi}

1949 Ortaokul Türkçe Programının "Yaziyle Ifade" başlığı altında yazma etkinliğiyle ilgili açıklamalarda bulunulmaktadır. Bu açıklamalara göre Türkçe dersleri bünyesinde öğrenciye gördüğünü, yaşadığını, duyduğunu, tasarladığını, okuduğunu ve düşündüğünü yazıyla doğru, düzgün, maksada uygun ve güzel olarak yazmak yetki ve cesaretini kazandırılmalıdır. Bu amaçla öğrencilerin bazı bilgi ve becerileri edinmesi gerekir. Bu bilgi ve beceriler programda şu maddelerle ifade edilmektedir (Temizyürek ve Balcı, 2006: 278):

a. Çevresini yakından tanıması ve tanıtması, icabettiği zaman bu konuda geniş bilgi verebilmesi,

b. Gözlem yeteneğinin, tertip ve anlatış kabiliyetinin geliştirilmesi,

c. Anlamını kavrıyarak kullandığı kelimelerin sayısını çoğaltması,

d. Yazacağı kelimeleri, cümle ve fikirleri yanlışsız olarak tertiplemeyi öğrenmesi,

e. Imla kurallarını bilerek uygulama alışkanlığını kazanmış bulunması.

Yukarıdaki maddelere göre bilgi, duygu ve düşüncelerini yazma cesareti hissederek anlatabilmeleri için öğrencilerin öncelikle güçlü bir gözlem yeteneğine sahip olmaları gerekmektedir. Ancak bu şekilde öğrenciler yaşadıkları çevreyi ayrıntılarıyla gözlemleyebilir ve bu gözlemlerini bir plana göre yazılı bir şekilde anlatabilirler. Yazma cesareti hissedebilmenin bir başka gerekliliği de kelime hazinesinin genişletilmeye çalışılmasıdır. Üçüncü madde olan "kavrıyarak kullandığı kelimelerin sayısını çoğaltması" bu duruma işaret etmektedir. Kelime hazinesi geniş olan bir öğrenci anlatmak istediği duygu ve düşüncelerini hedef kitleye ulaştırma sürecinde anlamını bildiği kelimeler arasından seçim yapma imkânına da sahip olacaktır. Buna karşın kelime hazinesi fakir olan bir öğrenci, anlatmak istediklerine uygun kelime bulamayabilecek ya da gayet kısır, kuru ve heyecansız kelimelerle bir metin oluşturmak zorunda kalacaktır.

1949 Ortaokul Türkçe Programının "Yaziyle ifade" başlığı altında yazma etkinliğiyle ilgili yapılan açıklamalara devam edilirken öğrencilerin yazma yetki ve cesareti kazanmalarının yanında onların meramlarını düzgün bir şekilde ifade etmeleri için kazanılması istenen alışkanlıklara da yer verilmiştir. Bunların da davranış/kazanım bağlamında değerlendirilmesi mümkündür. Bu alışkanlıklar aşağıdaki gibidir (Temizyürek ve Balcı, 2006: 279):

a. Karşısındakinin durumuna ve yazacağı konunun gereğine uygun bir şekilde yazmak,

b. Seviyeye uygun konulardan birisini açık ve okunabilir bir şekilde kaleme almak, fikirlerini bir veya birkaç paragrafla tertip ve tanzim edebilmek,

c. Okunan bir parça veya eserin ana hatlarını özetlemek,

d. Kendisini ilgilendiren bir yazın veya bilim konusunda araştırmalarda bulunmak ve bunları okuyanları ilgilendirecek şekilde yazmak, 
e. Küçük bir hikaye yazmak ve bazı hikayeleri piyes haline çevirebilmek,

$\mathrm{Bu}$ maddelere göre öğrencilerin meramlarını düzgün bir şekilde ifade edebilmeleri için yazılarında ele aldıkları konudan ayrılmadan onun gerekliliklerine uygun bir şekilde yazmaları, bir konu hakkındaki duygu ve düşüncelerini birkaç paragraf halinde ifade etmeleri gerekmektedir. Bu maddelerde ayrıca öğrencilerin metin türleri üzerinde çalışabilmeleri de ön görülmektedir. Örneğin öğrenciler küçük bir hikâye yazabilmeli veya bazı hikâyeleri piyes haline çevirebilmelidirler. Öğrencilerin yazıı anlatım becerisi açısından kazanmaları gereken diğer alışkanlıklar da herhangi bir metni özetleyebilmek ve kendi seviyelerine uygun bilimsel bir araştırmayı tamamlayarak ulaşılan sonuçları yazılı olarak anlatabilmektir.

1981 ilköğretim Okulları Türkçe Eğitimi Programına bakıldığında öğrencilere kazandırılmak istenen bilgi, beceri ve donanımın "davranış" kavramıyla karşılandığı görülmektedir. Programın mantığına göre davranış, her bir sınıf düzeyinde okuma, dinleme, yazma ve konuşma ile dil bilgisi alanlarında öğrencilerin kazanmaları gereken bilgi ve becerilerin toplamı şeklinde tanımlanabilir. Bu davranışlar 6., 7. ve 8. sınıf düzeylerinde ve her bir etkinlik alanı açısından ayrı ayrı belirlenmiştir. Bu durum yazma becerisi için de geçerlidir. Programın "Anlatım” genel başlığı altında "Öğrencilerin Kazanacakları Davranışlar" alt başlığı yer almaktadır. Buna göre öğrencilerin 6. sınıftan 8. sınıfın sonuna kadar yazılı olarak kazanmaları gereken davranışlar aşağıdaki tabloda gösterilmiştir.

Tablo 3. 1981 İlköğretim Okulları Türkçe Eğitimi Programında Yazma İle İlgili Davranışlar

\begin{tabular}{|c|c|c|c|}
\hline DAVRANIŞLAR & 6. SINIF & 7. SINIF & 8. SINIF \\
\hline $\begin{array}{l}\text { Yazım yanlısıı yapmadan yazabilmek, noktalama } \\
\text { işaretlerini doğru ve eksiksiz kullanabilmek; }\end{array}$ & 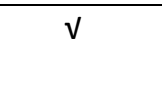 & $\mathrm{V}$ & v \\
\hline $\begin{array}{l}\text { Yerine göre türlü yapıdaki cümlelerle, doğru } \\
\text { olarak 4-5 cümlelik paragraflar kurabilmek; }\end{array}$ & $\checkmark$ & v & - \\
\hline $\begin{array}{l}\text { Türkçe derslerindeki her türlü etkinliklere } \\
\text { katılabilmek, varılan sonuçları anlatabilmek, } \\
\text { açıklayabilmek; }\end{array}$ & $\checkmark$ & v & $\mathrm{v}$ \\
\hline $\begin{array}{l}\text { Yakın çevreyi, bilinen bir köy, kasaba, kent vb.ni } \\
\text { kısaca anlatabilmek; }\end{array}$ & v & v & - \\
\hline $\begin{array}{l}\text { Bayram, tören, şölen, şenlik gibi hareketli bir } \\
\text { olayı, yerini ve orada olanları kısaca anlatabilmek; }\end{array}$ & $\checkmark$ & v & - \\
\hline $\begin{array}{l}\text { Özel mektuplar ve iş mektupları, zarf üstü } \\
\text { yazabilmek; }\end{array}$ & $\checkmark$ & v & v \\
\hline $\begin{array}{l}\text { Dilekçe, telgraf, alındı, senet yazabilmek, bir } \\
\text { karar, bir olay üzerine rapor düzenleyebilmek; }\end{array}$ & $\checkmark$ & v & v \\
\hline $\begin{array}{l}\text { Bir gezide görülenleri ve edinilen izlenimleri } \\
\text { anlatabilmek; }\end{array}$ & 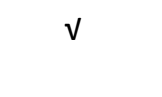 & v & v \\
\hline $\begin{array}{l}\text { Düzeylerine uygun kelime grupları, atasözü, } \\
\text { özdeyiş ve deyimleri açıklayabilmek; }\end{array}$ & $\checkmark$ & v & $\mathrm{v}$ \\
\hline $\begin{array}{l}\text { Türkçeden başka derslerle ilgili de olsa gözlem, } \\
\text { deney, sonuç ve açıklamaları, yazım ve söz dizimi } \\
\text { yanlışı yapmadan, noktalama işaretlerini doğru ve } \\
\text { eksiksiz kullanarak anlatabilmek }\end{array}$ & $\checkmark$ & v & v \\
\hline Okuduğu bir kitabı, izlediği bir filmi tanıtabilmek, & $\mathrm{v}$ & - & $\mathrm{v}$ \\
\hline
\end{tabular}




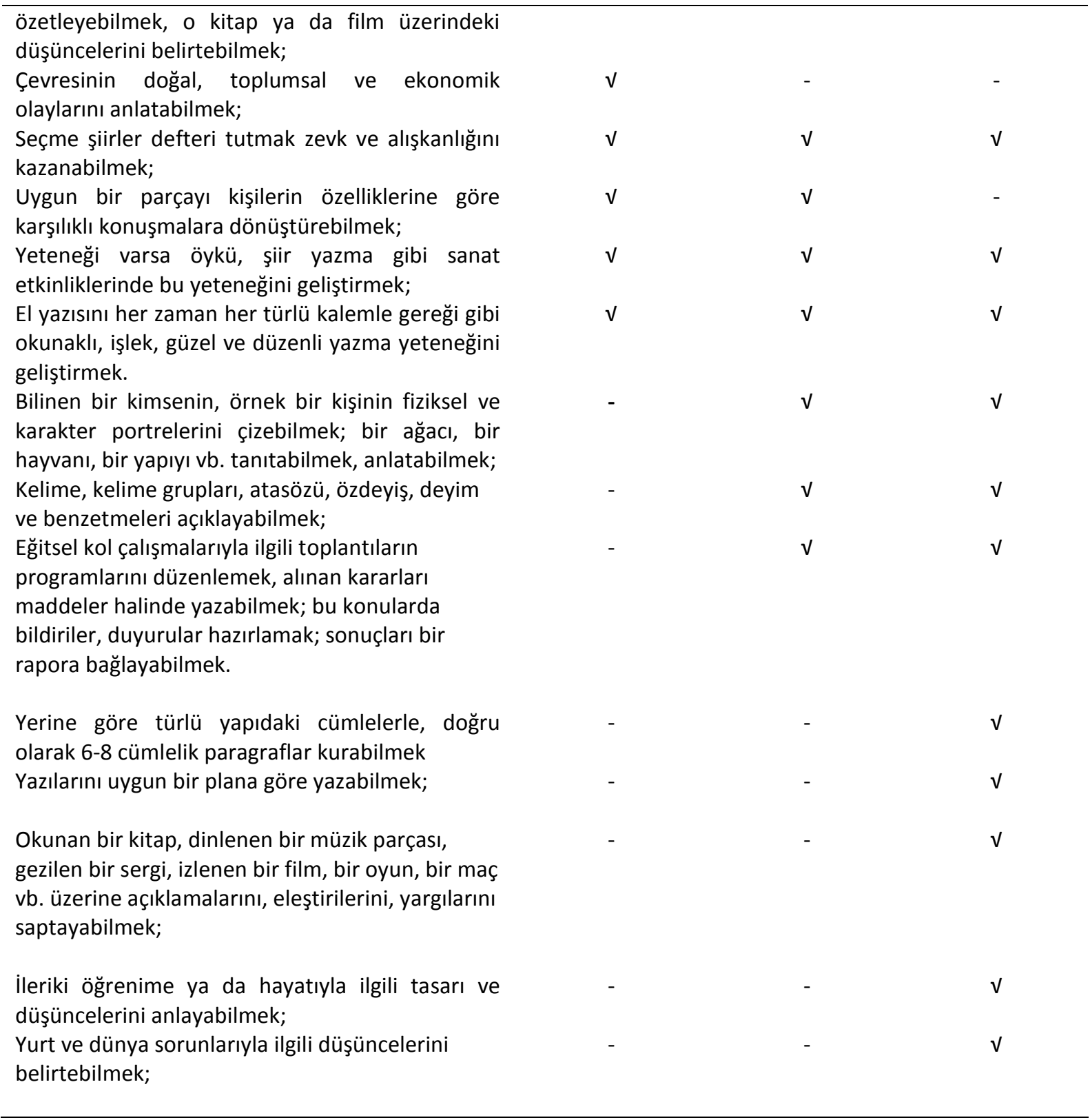

1981 illköğretim Okulları Türkçe Eğitimi Programında yazılı anlatımla ilgili davranışlar, içerik açısından çözümlenmeye çalışıldığında bazı başlıklar ortaya çıkmaktadır. Bunlar; yazı türlerine uygun metinler yazma, gözleme dayalı yazılar yazma, eleştiri yazıları yazma, açıklamaya dayalı yazma ve dil anlatım özelliklerine dikkat ederek yazma şeklinde ifade edilebilir.

Yazı türlerine uygun metinler yazma başlığı altında "Özel mektuplar ve iş mektupları, zarf üstü yazabilmek; dilekçe, telgraf, alındı, senet yazabilmek, bir karar, bir olay üzerine rapor düzenleyebilmek; seçme şiirler defteri tutmak zevk ve alışkanlığını kazanabilmek" davranışları yer almaktadır. Buradaki yazı türlerinin çerçevesi çok geniş tutulmuştur. Dilekçe, telgraf, alındı, rapor gibi bildirme yazıları, özel mektuplar, şiirler gibi edebi metinler bu çerçeveyi oluşturan başlıklardır. 
Gözleme dayalı yazılar yazma başlığı altında "Yakın çevreyi, bilinen bir köy, kasaba, kent vb.ni kısaca anlatabilmek; bayram, tören, şölen, şenlik gibi hareketli bir olayı, yerini ve orada olanları kısaca anlatabilmek; bir gezide görülenleri ve edinilen izlenimleri anlatabilmek; çevresinin doğal, toplumsal ve ekonomik olaylarını anlatabilmek" davranışları bulunmaktadır. Bu başlık altındaki davranışların sayıca çok olması, gözlem yeteneğinin ne derecede önemli olduğunun bir göstergesi olarak yorumlanabilir.

Eleştiri yazıları yazma başlığı altında "Okuduğu bir kitabı, izlediği bir filmi tanıtabilmek, özetleyebilmek, o kitap ya da film üzerindeki düşüncelerini belirtebilmek" şeklinde bir davranış cümlesi yer almaktadır. Gözlem yeteneğine dayalı davranış sayısının çok olmasının nedeni olarak gözlemin daha çok somut verilere dayalı olması gösterilirse; eleştiri yazma başlığı altındaki davranış cümlesinin tek olmasının gerekçesi de eleştirinin soyut düşünmeye dayalı olması şeklinde ifade edilebilir.

Açıklamaya dayalı yazılar yazma başlığı altında "Türkçe derslerindeki her türlü etkinliklere katılabilmek, varılan sonuçları anlatabilmek, açıklayabilmek; düzeylerine uygun kelime grupları, atasözü, özdeyiş ve deyimleri açıklayabilmek" olmak üzere iki davranış yer almaktadır. Öğrencilere açıklamaları için atasözü veya özdeyiş gibi kalıplaşmış ifadeler verilmekte ve bunların anlamlarına dayalı olarak onlardan yazılı metinler oluşturmaları beklenmektedir.

Son olarak dil ve anlatım özelliklerine dikkat ederek yazma başlığı altında bazı davranışların toplanabileceği görülmektedir. Bu davranışlar "Yerine göre türlü yapıdaki cümlelerle, doğru olarak 45 cümlelik paragraflar kurabilmek; yazım yanlışı yapmadan yazabilmek, noktalama işaretlerini doğru ve eksiksiz kullanabilmek; Türkçeden başka derslerle ilgili de olsa gözlem, deney, sonuç ve açıklamaları, yazım ve söz dizimi yanlışı yapmadan, noktalama işaretlerini doğru ve eksiksiz kullanarak anlatabilmek" şeklindedir. Burada ön plana çıkarılan düşünceler, doğru ve mantıklı cümleler kurabilmek, yazım yanlışı yapmadan yazabilmek ve noktalama işaretlerini doğru ve eksiksiz kullanmak şeklindedir.

2005 Türkçe Dersi Öğretim Programında öğrencilerin yatay olarak her yılın sonunda dikey olarak da 8. Sınıfın sonunda edinmeleri gereken bilgi, beceri ve alışkanlıklar, "Kazanım" olarak tanımlanmış ve okuma, yazma, dinleme, konuşma, dil bilgisi alanları doğrultusunda düzenlenmiştir. 2005 Türkçe Dersi Öğretim Programında yer alan kazanımlar, 1981 İlköğretim Okulları Türkçe Eğitimi Programındaki davranışlardan farklı olarak okuma, dinleme, konuşma ve yazma becerileri için her sınıf düzeyinde ortak olarak belirlenmiştir. Yalnızca dil bilgisi alanı için her sınıf düzeyinde farklı kazanımlara yer verilmiştir. Programda yazma becerisi doğrultusunda 6 amaç cümlesi ve bunların altında 42 kazanım bulunmaktadır. Programdaki amaç cümleleri "Yazma kurallarını uygulama, planlı yazma, farklı türlerde metinler yazma, kendi yazdıklarını değerlendirme, kendini yazılı olarak ifade 


\section{Cumhuriyet Dönemi Türkçe Eğitimi ve Öğretimi Programlarında Yazma Becerisi}

etme alışkanlığı kazanma ve yazım ve noktalama kurallarını uygulama" şeklindedir. Bu amaç cümleleri altında yer alan kazanımlar aşağıdaki tabloda verilmektedir.

Tablo 4. 2005 Türkçe Dersi Öğretim Programındaki Yazma Kazanımları

\begin{tabular}{|c|c|c|c|c|c|}
\hline $\begin{array}{l}\text { 1. Yazma } \\
\text { kurallarını } \\
\text { uygulama }\end{array}$ & 2. Planlı yazma & $\begin{array}{l}\text { 3. Farklı } \\
\text { türlerde } \\
\text { metinler } \\
\text { yazma }\end{array}$ & $\begin{array}{l}\text { 4.Kendi } \\
\text { yazdıklarını } \\
\text { değerlendir } \\
\text { me }\end{array}$ & $\begin{array}{l}\text { 5. Kendini yazılı } \\
\text { olarak ifade etme } \\
\text { alışkanlığı kazanma }\end{array}$ & $\begin{array}{l}\text { 6. Yazım ve } \\
\text { noktalama } \\
\text { kurallarını } \\
\text { uygulama }\end{array}$ \\
\hline $\begin{array}{l}\text { Kâğıt ve sayfa } \\
\text { düzenine dikkat } \\
\text { eder. }\end{array}$ & $\begin{array}{l}\text { Yazma konusu } \\
\text { hakkında } \\
\text { araştırma yapar. }\end{array}$ & $\begin{array}{l}\text { Olay } \\
\text { yazıları } \\
\text { yazar. }\end{array}$ & $\begin{array}{l}\text { Yazdıklarını biçim } \\
\text { ve içerik } \\
\text { yönünden } \\
\text { değerlendirir. }\end{array}$ & $\begin{array}{l}\text { Duygu, düşünce, } \\
\text { hayal, izlenim ve } \\
\text { deneyimlerini yazarak } \\
\text { ifade eder. }\end{array}$ & $\begin{array}{l}\text { Yazım } \\
\text { kurallarını } \\
\text { kavrayarak } \\
\text { uygular. }\end{array}$ \\
\hline $\begin{array}{l}\text { Düzgün, } \\
\text { okunaklı ve işlek } \\
\text { “bitişik eğik } \\
\text { yazı"yla yazar. }\end{array}$ & $\begin{array}{l}\text { Yazacaklarının } \\
\text { taslağını } \\
\text { oluşturur. }\end{array}$ & $\begin{array}{l}\text { Düşünce } \\
\text { yazıları } \\
\text { yazar. }\end{array}$ & $\begin{array}{l}\text { Yazdıklarını dil ve } \\
\text { anlatım } \\
\text { yönünden } \\
\text { değerlendirir. }\end{array}$ & $\begin{array}{l}\text { Yeni öğrendiği kelime, } \\
\text { kavram, atasözü ve } \\
\text { deyimleri kullanır. }\end{array}$ & $\begin{array}{l}\text { Noktalama } \\
\text { işaretlerini } \\
\text { işlevlerine } \\
\text { uygun olarak } \\
\text { kullanır. }\end{array}$ \\
\hline $\begin{array}{l}\text { Elektronik } \\
\text { ortamdaki } \\
\text { yazışmalarda } \\
\text { biçim ile ilgili } \\
\text { kurallara uyar. }\end{array}$ & $\begin{array}{l}\text { Yazısını bir ana } \\
\text { fikir etrafında } \\
\text { planlar. }\end{array}$ & $\begin{array}{l}\text { Bildirme } \\
\text { yazıları } \\
\text { yazar. }\end{array}$ & $\begin{array}{l}\text { Yazdıklarını yazım } \\
\text { ve noktalama } \\
\text { kurallarına } \\
\text { uygunluk } \\
\text { yönünden } \\
\text { değerlendirir. }\end{array}$ & İlgi alanına göre yazar. & \\
\hline $\begin{array}{l}\text { Standart Türkçe } \\
\text { ile yazar. }\end{array}$ & $\begin{array}{l}\text { Yazısının ana } \\
\text { fikrini yardımcı } \\
\text { fikirlerle } \\
\text { destekler. }\end{array}$ & Şiir yazar. & & Şiir defteri tutar. & \\
\hline $\begin{array}{l}\text { Türkçenin } \\
\text { kurallarına } \\
\text { uygun cümleler } \\
\text { kurar. }\end{array}$ & $\begin{array}{l}\text { Konunun } \\
\text { özelliğine uygun } \\
\text { düşünceyi } \\
\text { geliştirme } \\
\text { yollarını kullanır. }\end{array}$ & & & Günlük tutar. & \\
\hline $\begin{array}{l}\text { Yabancı } \\
\text { dillerden } \\
\text { alınmış, dilimize } \\
\text { henüz } \\
\text { yerleşmemiş } \\
\text { kelimelerin } \\
\text { yerine } \\
\text { Türkçelerini } \\
\text { kullanır. }\end{array}$ & $\begin{array}{l}\text { Atasözü, deyim } \\
\text { ve söz sanatlarını } \\
\text { uygun } \\
\text { durumlarda } \\
\text { kullanarak } \\
\text { anlatımını } \\
\text { zenginleştirir. }\end{array}$ & & & $\begin{array}{l}\text { Beğendiği sözleri, } \\
\text { metinleri ve şiirleri } \\
\text { derler. }\end{array}$ & \\
\hline $\begin{array}{l}\text { Olayları ve } \\
\text { bilgileri sıraya } \\
\text { koyarak anlatır. }\end{array}$ & $\begin{array}{l}\text { Yazdığı metni } \\
\text { görsel } \\
\text { materyallerle } \\
\text { destekler. }\end{array}$ & & & $\begin{array}{l}\text { Okul dergisi ve } \\
\text { gazetesi için yazılar } \\
\text { hazırlar. }\end{array}$ & \\
\hline Yazısında sebep- & Yazısına konunun & & & Yazdıklarını & \\
\hline
\end{tabular}




\begin{tabular}{|c|c|c|}
\hline $\begin{array}{l}\text { sonuç ilişkileri } \\
\text { kurar. }\end{array}$ & $\begin{array}{l}\text { ve türün } \\
\text { özelliğine uygun } \\
\text { bir giriş yapar. }\end{array}$ & $\begin{array}{l}\text { başkalarıyla paylaşır } \\
\text { ve onların } \\
\text { değerlendirmelerini } \\
\text { dikkate alır. }\end{array}$ \\
\hline $\begin{array}{l}\text { Yazısında amaç- } \\
\text { sonuç ilişkileri } \\
\text { kurar. }\end{array}$ & $\begin{array}{l}\text { Yazıyı etkileyici } \\
\text { ifadelerle sonuca } \\
\text { bağlar. }\end{array}$ & $\begin{array}{l}\text { Yazdıklarından arşiv } \\
\text { oluşturur. }\end{array}$ \\
\hline $\begin{array}{l}\text { Tekrara } \\
\text { düşmeden } \\
\text { yazar. }\end{array}$ & $\begin{array}{l}\text { Yazıya, konuyla } \\
\text { ilgili kısa ve } \\
\text { dikkat çekici bir } \\
\text { başlık bulur. }\end{array}$ & $\begin{array}{l}\text { Yazma yarışmalarına } \\
\text { katılır. }\end{array}$ \\
\hline $\begin{array}{l}\text { Yazım ve } \\
\text { noktalama } \\
\text { kurallarına uyar. }\end{array}$ & $\begin{array}{l}\text { Dipnot, } \\
\text { kaynakça, özet, } \\
\text { içindekiler vb. } \\
\text { kısımları uygun } \\
\text { şekilde düzenler. } \\
\text { Yazma yöntem ve } \\
\text { tekniklerini } \\
\text { kullanır. }\end{array}$ & \\
\hline
\end{tabular}

Tabloya göre öğrencilerin yazma becerileri geliştirilmeye çalışılırken öncelikle yazma kurallarını uygulamaya önem verilmelidir. "Standart Türkçe ile yazar, Türkçenin kurallarına uygun cümleler kurar, tekrara düşmeden yazar" gibi kazanımlar yazma kurallarını uygulamanın önemine işaret etmektedir. Programda yazma çalışmalarının planlı bir şekilde yürütülmesi üzerinde de durulmaktadır. Buna göre öğrenciler yazma etkinliklerini yürütürken öncelikle yazma konusu hakkında araştırma yapmalı, yazacaklarının bir taslağını çıkarmalı, yazmaya başlarken konunun ve türün özelliğine uygun bir giriş yapmalıdır. Programda ayrıca öğrencilerin olay yazıları, düşünce yazıları, bildirme yazıları ve şiir gibi farkı türlerde metinler yazmalarına, bu yazdıklarını içerik, dil anlatım, yazım ve noktalama yönlerinden değerlendirmeleri gerektiğine, şiir defteri tutma, günlük tutma, beğendiği atasözlerini ve özdeyişleri derleme gibi yazma alışkanlığı gerektiren etkinliklerde bulunmalarına da değinilmektedir. Sonuç olarak yukarıdaki yazma kazanımlarının içerdiği bilgi ve becerileri edinen öğrenciler, kendi yazma çalışmalarını kendileri yürütebilecekler, yazmaya karşı kendilerinde güven duygusu hissedecekler, kendi yazdıklarını değerlendirme yoluyla ürettikleri metinlerin olumlu ve olumsuz yönlerinin farkında olacaklardır.

\section{Cumhuriyet Dönemi Türkçe Eğitimi ve Öğretimi Programlarının "Düzeltme ve}

\section{Değerlendirme" Başlığı Doğrultusunda Yazma Becerisi}

Cumhuriyet dönemi Türkçe eğitimi ve öğretimi programlarında yazılı anlatım çalışmalarının düzeltilmesi ve değerlendirilmesine ilişkin ilk bilgiye 1929 Ortamektep Türkçe Programında 


\section{Cumhuriyet Dönemi Türkçe Eğitimi ve Öğretimi Programlarında Yazma Becerisi}

rastlıyoruz. Programda "Her sınıfta tahrir mevzularını verir ve tashih ederken nazarı dikkate alınacak noktalar" alt başlığı doğrultusunda beş maddeye yer verilmiştir. Bu maddelerden üç tanesi yazma çalışmalarında konu tespit ederken dikkat edilmesi gereken noktaları, diğer ikisi de doğrudan doğruya yazılı anlatım çalışmalarının düzeltilip değerlendirilmesi hususunu ele almaktadır. Bu iki madde "Tenkit, yazılan parçaların kusurlu cihetlerine olduğu gibi iyi cihetlerine de şamil olmalıdır." ve "Muallim talebesini kendi yanlışlarını bulup tashih etmeğe alıştırmalıdır." (Temizyürek ve Balcı, 2006: 239) şeklindedir.

Buna göre yazılı anlatım çalışmalarının düzeltilmesi ve değerlendirilmesi konusunda öğrencilerin hem psikolojik hem de bilişsel yönlerine değinilmiştir. "Tenkit, yazılan parçaların kusurlu cihetlerine olduğu gibi iyi cihetlerine de şamil olmalıdır." cümlesi, yazılanların hem olumlu hem de olumsuz yanlarının ortaya konması gerektiği bilgisini vermektedir. Öğretmen, yazma çalışmalarını değerlendirirken sadece olumsuz noktalara temas eder ve yazının iyi yönlerini görmezden gelirse öğrencinin bu türden çalışmalara yönelik olumsuz tutum geliştirmesi muhtemeldir. Ayrıca yazmaya karşı isteksizliğin ve yazmanın zor bir iş olduğu düşüncesinin yerleşme intimali de gözlenebilecek olumsuz davranışlardır. Buna karşın öğretmenin, yazma çalışmalarının iyi yönlerini de gündeme getirmesi ve öğrencilere takdir ifadeleriyle hitap etmesi, bir sonraki yazma çalışması için öğrenciyi güdüleyici bir işlev görecektir. Bütün bunlar düzeltme ve değerlendirme ile ilgili birinci maddenin öğrenciler üzerindeki psikolojik etkisini yansıtmaktadır.

Yazma çalışmalarının düzeltilmesi ve değerlendirilmesiyle ilgili olan "Muallim talebesini kendi yanlışlarını bulup tashih etmeğe alıştırmalıdır." şeklindeki ikinci madde bu işlemin bilişsel boyutuna değinmektedir. Buna göre öğrenciler zaman içinde kendi yazılarını değerlendirme ölçütlerini kavramalı ve bu işi kendileri yapabilmelidir. Ayrıca burada öz değerlendirme uygulamasının, sınırı bir şekilde de olsa yer aldığını görmek mümkündür.

1949 Ortaokul Türkçe Programında yazılı anlatım çalışmalarının düzeltilmesi ve değerlendirilmesi ile ilgili bilgilere "Yaziyle ifade" başlığının altında yer alan "Düzeltmeler" bölümünde rastlanmaktadır. Buradaki ifadeler şu şekilde kurulmuştur: "Yazma ödevlerinin düzeltilmesinde öğretmenin yanlışları hoş görürlügüu, ilk zamanlarda öğrencinin cesaretini kırmamak bakımından, faydalıdır. Fakat sonradan bunu sınırlamak lazımdır. Baştan ne kadar hoş görürlük, sonraki düzeltmelerde ne kadar titizlik gösterileceği ve bunun öğrencilere göre tek tek ayar edilmesi hususu öğretmene bırakılmıştır. Bu düzeltmelerde gelişmesi kontrol edilen ve öğretmen tarafından üstünde durulması gereken yetenekler, öğrencinin, gözlem, düşünme, hayalden canlandırma yetenekleri ile hafıza kuvveti, dili, imla ve yazı kurallarını, noktalama işaretlerini kullanmada başarı derecesi, ifadsindeki sadelik ve samimiliktir." (Temizyürek ve Balcı, 2006: 285).

Yukarıdaki ifadelerde başlıca iki noktaya değinilmektedir. Bunlardan birincisi yazma çalışmaları sırasında öğrencilere gösterilecek hoşgörü, ikincisi ise yazma çalışmalarının 
değerlendirilmesi sürecinde göz önünde bulundurulması gereken başlıklardır. Bunlardan birincisine göre yazma çalışmalarında öğrencilerin yazma cesaretlerinin kırılmaması amacıyla onlara özellikle çalışmaların başlangıç döneminde hoşgörü gösterilmelidir. Ancak çalışmaların ilerleyen dönemlerinde bu hoşgörünün nerede, ne zaman ve ne kadar gösterilmesi gerektiği konusu öğretmene bırakılmıştır. Yukarıdaki ifadelerde ele alınan konuların ikincisine göre öğretmenler yazma çalışmalarını değerlendirirken öğrencilerin gözlem ve düşünme yeteneklerini, hayal güçlerini ne kadar kullandıklarını, dili yapmacıktan uzak, samimi ve doğal bir şekilde kullanma durumlarını, imla kuralları ve noktalama işaretlerini ne kadar doğru uyguladıklarını göz önünde bulundurmalıdır.

1949 ortaokul Türkçe programında düzeltme yöntemlerine de değinilmektedir: Buna göre yazılı anlatım çalışmalarının değerlendirilmesinde şu yollara başvurulabilir (Temizyürek ve Balcı, 2006: 285):

a. Kendi kendine düzeltme,

b. Karşılıklı düzeltme,

c. Kümeler içinde düzeltme,

d. Sınıf̧̧a düzeltme,

e. Öğretmenin düzeltmesi,

Bu yöntemler uygulanırken hepsinin ortak amacı öğrenciyi kendi yaptığı yanlıştan kendi şuuru ile kurtarmak ve müşterek yanlışların önüne geçilmesini sağlamaktır. Programda, yazma çalışmalarının düzeltilmesi ve değerlendirilmesine ilişkin farklı yöntemlerden bahsedilmesinden hareketle, bu süreçte öğretmen ve öğrencinin birlikte yer aldığı, birden fazla değerlendirme aracının kullanııması gerektiği sonucu çıkarılabilir. Buradaki araçlar öz değerlendirme, akran değerlendirme ve öğretmenin kullanacağı farklı değerlendirme araçlarıdır. Programa göre bunlardan yalnız birisinin uygulanmasıyla yetinilmemeli, zaman zaman ötekilere de başvurulmalıdır. Bu düzeltme şekillerinin hangisi uygulanırsa uygulansın önemli olan, yanlışların öğrencilerin kendilerine buldurulmasıdır. Bu şekildeki bir uygulama, öğrencinin yapmış olduğu yanlışların sebebini kavramasını ve aynı yanlışı tekrar etmemesini sağlayacaktır.

Programda öğretmenin, yazılı çalışmalarını düzeltip değerlendirirken göz önünde bulundurması gereken başlıkların ayrıntılarına maddeler halinde değinilmiştir. Buna göre öğretmenlerin, yazılı anlatım çalışmalarını değerlendirirken şu noktalara dikkat etmeleri gerekir (Temizyürek ve Balcı, 2006: 286):

a. Bizzat yaşanmış olayla onun anlatılışı birbirine denk geliyor mu?

b. Öğrencinin artık duymadığı halde, vazife uzun olsun diye, devam ettiği oluyor mu?

c. Öğrenci herhangi bir sebeple ana fikri unutarak ayrıntılara gidiyor ve bir daha ana fikre dönemiyor mu? 


\section{Cumhuriyet Dönemi Türkçe Eğitimi ve Öğretimi Programlarında Yazma Becerisi}

d. Iyi gözlemli ödevler yanında bazı öğrencilerin pek sönük ödevler vermelerinin sebepleri nelerdir?

e. Kusurlu bir üslup içinde de olsa bir düşüncenin varlığı seziliyor mu?

f. Fikirlerin planı, duygu ve düşüncelerin sıralanışı uygun mu?

g. Yersiz sözlere, kelime oyunlarına özeniliyor mu?

h. Verilen zaman iyi kullanılmıs mı?

i. Daha eski ödevlerde düzeltilen ve sınıfça üzerinde durulan yanlışlardan korunuluyor mu?

j. Şive yanlışları var mı?

$\mathrm{Bu}$ maddelere bakıldığında öğrencilerin yazılarında öncelikle bir konunun ve bu konu aracılığıyla bir ana fikrin varlığı sezdirilmelidir. Bu konu ve ana fikir sağlam bir plana göre metin içine yerleştirilmeli ve gereksiz sözlerle uzatılmamalıdır. Bununla birlikte yazıda ele alınan konu ve ana fikir uygun bir dil ve anlatım tarzı ile işlenmeli, kelime oyunlarına girişilmeden açık ve anlaşılır bir şekilde ifade edilmelidir.

1981 ilköğretim Okulları Türkçe Eğitim Programında yazılı anlatım çalışmalarının düzeltilmesi ve değerlendirilmesine iki başlık altında yer verilmelidir. Bunlar "Yöntem" ve "Ölçme ve Değerlendirme" başlıklarıdır. Programın "Yöntem" başlığı altındaki ifadeler aşağıdaki gibidir:

“Öğrencilerin sözlü ve yazılı anlatım (kompozisyon) ödevlerini incelerken öğretmen, bu tür çalışmalara ilgi uyandırma, sevdirme, cesaretlendirme görevini yerine getirmede çok duyarlı olmalıdır. Öğrenciden bir sanat eseri değil, amacını doğru ve tam anlatabilmesi istenmelidir. Gereksiz süslemelerle; boş lâflarla değil; olayları, düşünceleri ya da duyguları mantıkla, düşünerek usa vurarak açık, olduğu gibi, yalın olarak anlatmakla başarılı olunacağı kavratılmalıdır. Bu, örnekler verilerek ve öğrenci ödevleri üzerinde gerekli ve yerinde eleştiriler yapılarak gerçekleştirilmelidir." (Temizyürek ve Balcı, 2006: 395).

Buradaki ifade tersinden başlanarak okunmaya çalışılırsa öğrencilerin yazma çalışmalarını değerlendirmenin amacına ulaşmak mümkündür. Öğretmen öğrencinin yazısını değerlendirmekle ona yazma becerisinde gereksiz süslemelerle; boş lâflarla değil; olayları, düşünceleri ya da duyguları mantıkla, düşünerek usa vurarak açık, olduğu gibi, yalın olarak anlatmakla başarılı olabileceğini kavratmayı amaçlamaktadır. Yukarıdaki ifadelerden yazma çalışmalarını değerlendirirken takip edilmesi gereken yönteme ilişkin yorumlara da ulaşmak mümkündür. Buna göre öğretmen, öğrencilerin yazılı anlatım çalışmalarını değerlendirirken, bu çalışmalara ilgi uyandırma, bunları sevdirme, bunlara karşı cesaretlendirme görevini yerine getirmede çok duyarlı olmalıdır.

1981 Programının "Yöntem" başlığı altında düzeltme ve değerlendirme sürecine ilişkin diğer ifade şu şekildedir: 
"Yazılı ödevler mutlaka düzeltilmelidir. Bir ödevdeki yanlışları birden belirtmek öğrenciyi korkutarak ümitsizliğe düşürebilir. Önce en çok yapılan ve önemli olan yanlış üzerinde durulmalı, ondan sonra öbür yanlışlar sistemli olarak ele alınıp düzeltilmelidir. Bu düzeltmeler olumlu bir eleştirme biçiminde olmalıdır. Yanlışların doğruları, öğrencilerin kendilerine buldurulmalı, uygulamalar yaptırılarak kavratılmalı ve benimsetilmelidir." (Temizyürek ve Balcı, 2006: 395).

Yukarıdaki bölümde yazma çalışmalarının düzeltilmesi ve değerlendirilmesi konusunda önemli bazı noktalara değinilmektedir. Buna göre öğrencilerin yanlışları değerlendirilirken yazma cesaretlerinin kırılmaması ve yazmaya karşı isteksizlik göstermelerinin önüne geçilmesi amacıyla önce en büyük ve önemli yanlışlardan başlanmalı, giderek daha küçük çaptaki yanlışların düzeltilmesine devam edilmelidir. Bu konudaki diğer önemli nokta da yanlışların öğrencilerin kendilerine buldurulmasıdır. Bu şekilde öğrenci nerede, hangi yanlışı yaptığını ve bunların nasıl düzeltilmesi gerektiğini bizzat görerek kavrayacaktır.

Programın "Ölçme ve Değerlendirme" başlığı altında düzeltme ve değerlendirme ile ilgili olarak öğrencilerin yazılarında aranması gereken özelliklere yer verilmektedir. Bu özellikler, aşağıdaki gibidir (Temizyürek ve Balcı, 2006: 402):

a. Duygu, düşünce ve tasarıları;

b. Olaylara bakış açısı;

c. Olaylar, gözlemler, izlenimler,

d. Plân ve anlam bütünlüğü,

e. Anlatımda tabiîlik, duruluk,

f. Dilde doğruluk, uygun kelimelerin seçilmesi, yerinde kullanılması, cümle kuruluşunda doğruluk,

g. Yazım ve noktalama işaretleri,

h. Yazının sayfaya iyi yerleştirilmesi.

Bu maddelere bakıldığında yazma çalışmalarında içerik, anlatım ve dış yapı özelliklerinin ön plana çıkarıldığı görülmektedir. Öğrenciler içerik anlamında yazılarında duygu, düşünce ve tasarılarına uygun bakış açısını kullanarak ve bir plan dahilinde yer vermelidirler. Ayrıca bu duygu, düşünce ve tasarılarını anlatımda tabiîliği ve duruluğu sağlayarak ve uygun kelimelerin seçilmesiyle doğru cümleler kurarak ifade etmelidirler. Son olarak, yazının sayfa üzerine estetik bir şekilde yerleştirilmesi, öğrencilerin yazılarında aranması gereken dış yapı özelliklerinden birisi olarak değerlendirilebilir.

2005 Türkçe Dersi Öğretim Programında yazılı anlatım çalışmalarının düzeltilmesi ve değerlendirilmesi konusunda kısa bir açıklama yer almaktadır. Buna göre yazma çalışmalarının istenen amaçlara ulaşabilmesi, yapılan etkinliklerin değerlendirilmesiyle mümkündür. Programda, 
öğrencinin kendi yazdıklarını değerlendirme ölçütlerine yer verilerek yalnızca öğretmenin değil, öğrencinin kendisinin ve arkadaşlarının da bu sürece katılması amaçlanmıştır.

\section{Sonuç}

Cumhuriyet dönemi Türkçe eğitimi ve öğretimi programlarında yazma becerisinin hangi boyutlarıyla yer aldığını tespit etmek amacıyla yapılan bu araştırmada 1924 Lise Birinci Devre Müfredat Programı, 1929 Ortamektep Türkçe Programı, 1949 Ortaokul Türkçe Programı, 1981 İlköğretim Okulları Türkçe Eğitim Programı ve 2005 İlköğretim Türkçe Dersi (6, 7, 8. Sınıflar) Öğretim Programı içerik açısından incelenmiş ve varılan sonuçlar aktarılmaya çalışıımıştır. Araştırmaya konu olan Türkçe programları "genel amaçlar, açıklamalar, yöntem, davranış/kazanım, düzeltme/değerlendirme başlıkları açısından değerlenmiştir. Bunlardan "amaçlar" başlığı 1924 Lise Birinci Devre Müfredat Programının dışındaki Türkçe eğitim öğretim programlarında; "açıklamalar" başlığı incelenen tüm Türkçe eğitim öğretim programlarında; "yöntem" ile "davranış/kazanım" başlı̆ı 1981 Ilköğretim Okulları Türkçe Eğitim Programı ve 2005 ilköğretim Türkçe Dersi Öğretim Programlarında; "düzeltme ve değerlendirme başlı̆̆ı" ise 1949 ve 1961 Ortaokul Türkçe Programı, 1981 Illköğretim Okulları Türkçe Eğitim Programı ve 2005 Illköğretim Türkçe Dersi Öğretim Programlarında ortak olarak yer almaktadır.

Amaçlar başlı̆ı 1929 Ortamektep Türkçe Programından itibaren 2005 Türkçe Dersi Öğretim Programına kadar bütün programlarda yer almış ve araştırma boyunca kendi içinde "genel amaçlar" ve "özel amaçlar" olmak üzere ikiye ayrılmıştır. Genel amaçlar başlığı altında okullarda okutulmakta olan Türkçe dersleri ile öğrencilere kazandırılmak istenen bilgi ve beceriler amaç cümleleri şeklinde ifade edilmektedir. Araştırmada bu amaç cümlelerinden yazma becerisi ile ilgili olanlar değerlendirilmiştir. Yazma becerisiyle ilgili olarak 1929 Ortamektep Türkçe Programında "Talebeyi meramını ağızdan ve yazı ile ifade etmeye alıştırmak; 1949 Ortaokul Türkçe Programında "Onlara gördüklerini, duyduklarını, bildiklerini, incelediklerini, öğrendiklerini, düşünüp tasarladıklarını söz ve yazı ile doğru olarak anlatma kudretini kazandırmak." ve "Dilimizin bağıı olduğu ana kuralları sezdirip öğreterek, onlara Türk dilini kullanmada güven sağlamak; 1981 İlköğretim Okulları Türkçe Eğitim Programında "Onlara, görüp izledikelrini, dinlediklerini, okuduklarını, incelediklerini ve düşündüklerini, tasarladıkalıını söz ya da yazı ile doğru ve amaca uygun olarak anlatma beceri ve alışkanlığını kazandırmak; öğrencilere Türk dilini sevdirmek, kurallarını sezdirmek; onları, Türkçeyi gelişim süreci içinde bilinçle, özenle ve güvenle kullanmaya yöneltmek; 2005 Türkçe Dersi Öğretim Programında "Duygu, düşünce ve hayallerini sözlü ve yazılı olarak etkili ve anlaşılır biçimde ifade etmeleri; Türkçeyi, konuşma ve yazma kurallarına uygun olarak bilinçli, doğru ve özenli kullanmaları." maddelerine yer verilmektedir. Özel amaçlar başlığı ise incelenen programların salt yazma becerisine yönelik bölümlerinde bulunmaktadır. Örneğin 1929 Ortamektep Türkçe Programında "Tahrir Derslerinin Gayesi"; 1949 Ortamektep Türkçe Programında "Söz ve Yaziyle ifade" ile "Imlâ"; 1981 
Ilköğretim Okulları Türkçe Eğitim Programında ise "Anlatım" başlıkları altında yazma becerisine yönelik özel amaçlardan bahsedilmektedir.

Açıklamalar başlığı 1924'ten 2005 yılına kadar bütün programlarda yer almaktadır. 1924 Lise Birinci Devre Müfredat Programının "Lise Müfredat Programlarının Esbâb-ı Mûcibe Lâyihası" kısmında yazma becerisiyle ilgili en önemli bilgi "Tahrir mevzuları hayattaki ihtiyaçlara tekabül etmelidir." maddesiyle verimektedir. 1929 Ortamektep Türkçe Programının "Umumî Mülahazalar" başlı̆̆ı altında yazma becerisiyle konuşma becerisinin birlikte geliştirilmesi gerektiğinden bahsedilmektedir. 1949 Ortaokul Türkçe Programında yazııı anlatım becerisine yönelik açıklamalara "Genel Olarak Söz ve Yaziyle ifade", "Yaziyle ifade" ve "imla" başlıkları altında yer verilmiştir. Bu başlıklar doğrultusunda genel olarak yazmanın "sözün zaman ve mekân içinde yayılmasını sağlıyan tek araç" olduğu, bu nedenle öğretmenin "bir yandan öğrencilerinin meramlarını sözle ifade etmelerine imkân verirken bir yandan da yazılı anlatmaya imkân ve fırsatlar hazırlaması" gerektiği gibi noktalar üzerinde durulmaktadır. 1981 Illköğretim Okulları Türkçe Eğitim Programının "Açıklamalar" bölümünde yazma becerisine geniş bir yer verilmektedir. Bu başlık altında yazma becerisi öncelikle karşııklı anlaşmayı sağlaması yönüyle ele alınmaktadır. Buna göre insanların birbirleriyle anlaşabilmelerinin iki yönü vardır. Birincisi söylenenleri, okunanları anlamak ikincisi ise bilgi, duygu, düşünce ve tasarıları sözle ya da yazı ile anlatmaktır. 2005 Türkçe Dersi (6. 7. 8. Sınıflar) Öğretim Programında yazma becerisi ile ilgili açıklamalar "Temel Dil Becerileri" başlığı altında yer almaktadır. Burada yazma becerisinin işlevinden bahsedilmektedir. Buna göre yazılı anlatım, bireyin kendini doğru ve amacına uygun olarak ifade etmesinde ve iletişim kurmasında en etkili araçlardan biridir.

Yöntem müstakil olarak 1981 Illköğretim Okulları Türkçe Eğitim Programı ile 2005 Türkçe Dersi Öğretim Programında yer verilmiştir. Diğer programlarda doğrudan yöntem başlığı yoktur ancak diğer başlıklar altında yapılan bazı açıklamalar yöntemle ilişkilendirilmiştir. 1924 Lise Birinci Devre Müfredat Programının "Türkçe Programının Esbab-ı Mûcibesi" başlığı altında yazma çalışmalarııın nasıl yürütülmesi gerektiğine dair bilgiler bulunmaktadır. 1929 Ortamektep Türkçe Programına göre "Tahrir mevzuları verilirken talebenin onları yazması için içtimaî bir saik bulunması çok faydalı olur." Ayrıca "yazdırılacak mevzular üzerine bazan evelce şifahî mükôleme yapmak ve bu mükâleme üzerine plân çizmek faydalıdır." 1949 Ortaokul Türkçe Programındaki yönteme ilişkin bilgiler genellikle yazma konularının seçimi ve işlenmesi üzerine kurulmuştur. Buna göre "ilk sınıfların yazma konularında somuttan başlıyarak soyuta doğru gidilmeli, evvela yaşanmış konuların hazırlanmasına önem verilmelidir." 1981 İlköğretim Okulları Türkçe Eğitim Programının "Yöntem" başlığı altında okuma parçalarının nasıl işlenmesi gerektiğine, anlatım çalışmalarına, dil bilgisi etkinliklerinin yürütülmesine ilişkin bilgiler vardır. Bu bölümde yazma etkinliklerine "Anlatım Çalışmaları" alt başlığı altında değinilmiştir. Buna göre yazma çalışmaları için ayrı bir ders saati beklenmemeli, anlama etkinliğinden 


\section{Cumhuriyet Dönemi Türkçe Eğitimi ve Öğretimi Programlarında Yazma Becerisi}

normal bir akış sağlanarak yazmaya geçilmeli, böylece anlama ve anlatma etkinlikleri eşgüdüm içinde yürütülmelidir. 2005 Türkçe Dersi (6-8. Sınıflar) Öğretim Programında diğer dil becerilerinde olduğu gibi yazma becerisine yönelik yöntemlere yer verilmiştir. Bu yöntemlerin amacı genel olarak öğrencilerin hangi alanlarda ve türlerde yazma yeteneklerinin olduğunu belirlemek ve onları uygun yazma yöntem ve türlerine yönlendirmektir.

Davranış / Kazanım başlığına ilişkin ilk bilgiler, -bu şekilde bir başlık içermese de- 1949 Ortaokul Türkçe Programında yer almaktadır. Buna göre Türkçe dersleri bünyesinde öğrenciye gördüğünü, yaşadığını, duyduğunu, tasarladığını, okuduğunu ve düşündüğünü yazıyla doğru, düzgün, maksada uygun ve güzel olarak yazmak yetki ve cesareti kazandırılmalıdır. 1981 illköğretim Okulları Türkçe Eğitimi Programına bakıldığında öğrencilere kazandırılmak istenen bilgi, beceri ve donanımın "davranış" kavramıyla karşılandığı görülmektedir. Programın "Anlatım" genel başlığı altında "Öğrencilerin Kazanacakları Davranışlar" alt başığı yer almaktadır. Burada öğrencilerin yazılı olarak kazanmaları gereken davranışlara yer verlmektedir. 2005 Türkçe Dersi Öğretim Programında öğrencilerin yatay olarak her yılın sonunda dikey olarak da 8. Sınıfın sonunda edinmeleri gereken bilgi, beceri ve alışkanlıklar, "kazanım" olarak tanımlanmıştır. Bu kazanımlar, 1981 illköğretim Okulları Türkçe Eğitimi Programındaki davranışlardan farklı olarak her sınıf düzeyinde ortak bir şekilde belirlenmiştir. Programda yazma becerisi ile ilgili olarak 6 amaç cümlesi ve bunların altında 42 kazanım bulunmaktadır.

Düzeltme ve değerlendirme başlğı doğrultusundaki ilk bilgiye 1929 Ortamektep Türkçe programında rastlanır. Buna göre öğrenciler yazma çalışmalarında kendi yanlışlarını bulmaya alıştırılmalıdır. 1949 ortaokul Türkçe programında yazılı anlatım çalışmalarının düzeltilmesi ve değerlendirilmesi ile ilgili bilgilere "Yaziyle ifade" başlığının altında yer alan "Düzeltmeler" bölümünde rastlanmaktadır. Burada yazma çalışmaları sırasında öğrencilere gösterilecek hoşgörü ve yazma çalışmalarının değerlendirilmesi sürecinde göz önünde bulundurulması gereken noktalar ifade edilmektedir. Ayrıca yazma çalışmalarını düzeltme yöntemlerine de değinilmektedir. 1981 ilköğretim okulları Türkçe eğitim programında yazılı anlatım çalışmalarının düzeltilmesi ve değerlendirilmesine "Yöntem" ve "Ölçme ve Değerlendirme" başıkları altında yer verilmektedir. Yöntem başlığı altında öğrencilerin yazııı anlatım çalışmalarını değerlendirirken, bu çalışmalara ilgi uyandırma, bunları sevdirme, bunlara karşı cesaretlendirme gibi noktaların göz önünde bulundurulması gerektiği ifade edilmiştir. Ölçme ve Değerlendirme başlığı altında öğrencilerin yazılarında aranması gereken özelliklere yer verilmektedir. 2005 Türkçe Dersi Öğretim Programında ise yazma çalışmalarının istenen amaçlara ulaşabilmesinin yapılan etkinliklerin değerlendirilmesiyle mümkün olacağı ifade edilmektedir. 


\section{Kaynakça}

Aktaş, Ş. - Gündüz, O. (2002). Yazılı ve Sözlü Anlatım. Ankara: Akçağ Yayınları.

Balcı, A. - Coşkun, E. ve Tamer, M. (2012). Cumhuriyet dönemi Türkçe dersi öğretim programlarının genel amaçları bakımından değerlendirilmesi. Dil ve Edebiyat Eğitimi Dergisi, 1(1), 1-13.

Bülbül, A.R. (2000). Yazılı Anlatım ve Yazı Türleri. Ankara: Nobel Yayın Dağıtım.

Eyüp, B. (2008). İlköğretim İkinci Kademe 1981 Ille 2005 Türkçe Programlarının Karşılaştırılmalı Olarak Incelenmesi. Atatürk Üniversitesi, Sosyal Bilimler Enstitüsü, Türkçe Eğitimi Anabilim Dalı, Yayımlanmamış Yüksek Lisans Tezi.

Fer, S. (2005). 1923 Yılından Günümüze Cumhuriyet Dönemi Illköğretim Programları Üzerine Bir İnceleme. Cumhuriyet Dönemi Eğitim Politikaları Sempozyumu. Marmara Üniversitesi Atatürk Eğitim Fakültesi ve Atatürk Araştırma Merkezi, 7-9 Aralık, İstanbul.

Girgin, Y. (2011). Cumhuriyet Dönemi (1929-1930, 1949,1981) Ortaokul Türkçe Öğretimi Programlarının İçerik, Genel ve Özel Amaçlarıyla Karşılaştırmalı Gelişim Düzeyi. Adnan Menderes Üniversitesi Eğitim Fakültesi, Eğitim Bilimleri Dergisi, 2 (1), 11-26.

Gömleksiz, M. N. Sinan, A. T. ve Demir, S. (2011). Illköğretim İkinci Kademe Türkçe Dersi Öğretim Programındaki “Okuma” Öğrenme Alanına illişkin Kazanımların Gerçekleşme Düzeyine Yönelik Öğretmen Görüşleri. Fırat Üniversitesi Sosyal Bilimler Dergisi. Cilt 21, Sayı 1, ss. 169-196.

İşeri, K. (2007). Altıncı Sınıf Türkçe Ders Kitabının İlköğretim Türkçe Programının Amaçlarına Uygunluğunun Değerlendirilmesi. Dil Dergisi, S 136, ss. 58-74.

Karasar, N. (2009). Bilimsel Araştırma Yöntemleri. Nobel yayınevi. Ankara.

Kılıç, D. (2003). Öğretmenlik Mesleğine Giriş, Aktif Yayınevi, Erzurum.

Özbay, M. (2006). Türkçe Özel Öğretim Yöntemleri I. Ankara: Öncü Basımevi.

Özbay, M., İlköğretim Okulları Türkçe Ders Kitaplarındaki Anlama Sorularının Öğrencilerin Düşünme Becerilerine Katkısı, Türk Dili Dergisi, Sayı: 609, Sayfa: 536-546, 2002.

Özbay, M. - Melanlığlu, D. (2012). Türkçe Öğretim Programlarının Dinleme Becerisi Bakımından Değerlendirilmesi. Turkish Studies. Sayı 7/1, ss. 87-97.

Özkırımlı, A. (2002). Türk Dili Dil ve Anlatım, Yaşayan Türkçe Üzerine Bir Deneme. İstanbul: İstanbul Bilgi Üniversitesi Yayınları.

TDK. (2005). Türkçe Sözlük. Türk Dil Kurumu Yayınları. Ankara.

Tekin, H. (1991). Eğitimde Ölçme ve Değerlendirme, Yargı Yayınları, Ankara.

Temizyürek, F. - Balcı, A. (2006). Cumhuriyet Dönemi Ilköğretim Okulları Türkçe Programları, Ankara: Nobel Yayın Dağıtım.

Yaman, H. (2009). İlköğretim Türkçe Dersi Programı'nın Kalabalık Sınıflarda Uygulanabilirliğine İlişkin Öğretmen Görüşleri. Kuram ve Uygulamada Eğitim Bilimleri. 9 (1), 2009, ss. 329-359.

Yıldırım, A. ve Şimşek, H. (2008). Sosyal Bilimlerde Nitel Araştırma Yöntemleri. Ankara: Seçkin Yayıncılık. 